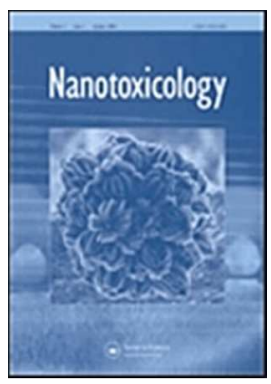

\title{
Soil pH effects on the comparative toxicity of dissolved zinc, non-nano and nano ZnO to the earthworm Eisenia fetida
}

\begin{tabular}{|r|l|}
\hline Journal: & Nanotoxicology \\
\hline Manuscript ID: & TNAN-2012-0229.R1 \\
\hline Manuscript Type: & Original Article \\
\hline Complete List of Authors: & $\begin{array}{r}\text { Heggelund, Laura; University of Copenhagen, Department of Basic Science } \\
\text { and Environment } \\
\text { Diez-Ortiz, Maria; Natural Environment Research Council, Centre for } \\
\text { Ecology and Hidrology (CEH), } \\
\text { Lofts, Stephen; Centre for Ecology and Hidrology, } \\
\text { Lahive, Elma; Natural Environment Research Council, Centre for Ecology \& } \\
\text { Hydrology (CEH) } \\
\text { Jurkschat, Kerstin; Oxford University, } \\
\text { Wojnarowicz, Jacek; Polish Academy of Sciences, Institute of High Pressure } \\
\text { Physics (UNIPRESS) } \\
\text { Cedergreen, Nina; University of Copenhagen, Department of Basic Science } \\
\text { and Environment } \\
\text { Spurgeon, David; Centre for Ecology and Hydrology, } \\
\text { Svendsen, Claus; } ; \text { Natural Environment Research Council, Centre for } \\
\text { Ecology \& Hydrology (CEH) }\end{array}$ \\
\hline Keywords: & \begin{tabular}{l} 
zinc oxide, nanoparticle, Nanotoxicology, soil pH, earthworms \\
\hline
\end{tabular} \\
\hline
\end{tabular}


1

2

3

4

5

6

7

8

9

10

11

12

13

14

15

16

17

18

19

20

21

22

23

24

25

26

27

28

29

30

31

32

33

34

35

36

37

38

39

40

41

42

43

44

45

46

47

48

49

50

51

52

53

54

55

56

57

58

59

60

Soil pH effects on the comparative toxicity of dissolved zinc, non-nano and nano $\mathrm{ZnO}$ to the earthworm Eisenia fetida

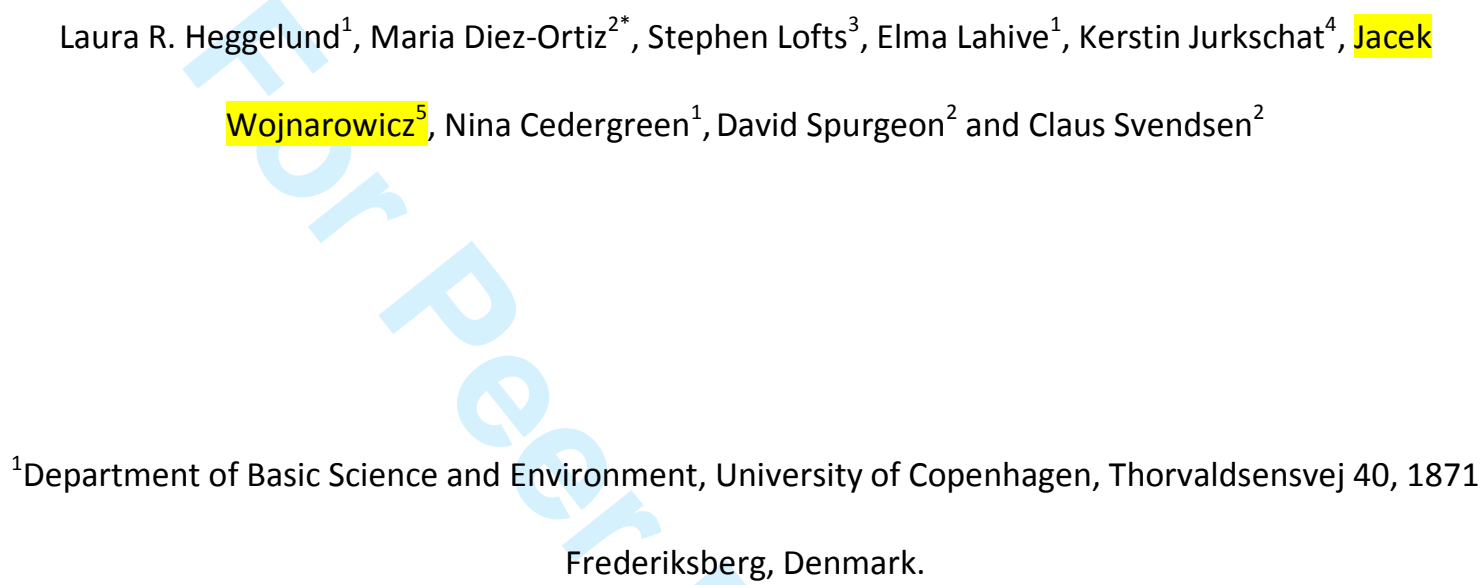

${ }^{2}$ Centre for Ecology and Hydrology, Maclean Building, Benson Lane, Crowmarsh Gifford, Wallingford, Oxfordshire OX10 8BB, UK

${ }^{3}$ Centre for Ecology and Hydrology, Library Avenue, Bailrigg, Lancaster, LA1 4AP, UK

${ }^{4}$ Department of Materials, Oxford University, Begbroke Science Park, Sandy Lane, Yarnton, Oxford, OX5 1PF, UK

${ }^{5}$ Polish Academy of Sciences, Institute of High Pressure Physics (UNIPRESS), Sokolowska 29/37, Warszawa 01-142, Poland

*Corresponding author, e-mail: marezo@ceh.ac.uk 


\begin{abstract}
To determine how soil properties influence nanoparticle (NP) fate, bioavailability and toxicity, this study compared the toxicity of nano zinc oxide ( $\mathrm{ZnO} \mathrm{NPs}$ ), non-nano $\mathrm{ZnO}$ and ionic $\mathrm{ZnCl}_{2}$ to the earthworm Eisenia fetida in a natural soil at three $\mathrm{pH}$ levels. NP characterisation indicated that reaction with the soil media greatly control $\mathrm{ZnO}$ properties. Three main conclusions were drawn. Firstly that $\mathrm{Zn}$ toxicity, especially for reproduction, was influenced by $\mathrm{pH}$ for all $\mathrm{Zn}$ forms. This can be linked to the influence of $\mathrm{pH}$ on $\mathrm{Zn}$ dissolution. Secondly that $\mathrm{ZnO}$ fate, toxicity and bioaccumulation were similar (including relationships with $\mathrm{pH}$ ) for both $\mathrm{ZnO}$ forms, indicating the absence of NP specific effects. Finally earthworm $\mathrm{Zn}$ concentrations were higher in worms exposed to $\mathrm{ZnO}$ compared to $\mathrm{ZnCl}_{2}$, despite the greater toxicity of the ionic form. This observation suggests the importance of considering the relationship between uptake and toxicity in nanotoxicology studies.
\end{abstract}

\title{
Keywords
}

Zinc oxide, nanoparticle, nanotoxicology, soil pH, earthworms 


\section{Introduction}

The field of nanotechnology has received increasing attention in the last decade resulting in a range of new innovations. This development is driven by the potential for industries to improve goods and processes by exploiting the unique properties of materials when fabricated at the nanoscale (Christian, 2009). The potential of engineered NPs is in great part due to their increased surface area and, thereby, their high surface energy and reactivity. These properties can set them apart from their bulk (i.e non nanoscale) counterparts.The fact that NPs can be produced in a highly specific manner to fit a certain purpose is very attractive to industry and underpins their applications and growth potential (Christian, 2009). In 2004 the estimated production volume of NPs was only 2000 tons per year. This production is, however, predicted to increase to more than 50,000 tons per year by 2020 (PROSPECT, 2009).

As a direct consequence of their current commercial aplications, e.g. in cosmetics, antimicrobial applications and industrial processing, manufactured NPs are increasingly being released into waste water systems. In many countries (including the UK), sewage sludge is routinely spread to agricultural land as fertilizer. This application creates a direct exposure route for NPs to terrestrial ecosystems (Benn \& Westerhoff, 2008; Johnson et al., 2011). Very few analytical techniques for measuring NPs in natural systems are available. This results in a lack of data on their occurrence in the environment (Nowack \& Buchelli, 2007). However, modelling studies have suggested that concentrations of NPs reaching soil could result in concentrations ranging from the low nanogram (fullerenes) to approximately $100 \mu \mathrm{g} / \mathrm{kg}$ (nano $\mathrm{TiO}_{2}$ ) concentrations depending on the assumptions made concerning market development and post use release fate (see Gottschalk et al. 2009, Johnson et al. 2011). 
Once in the environment the exposure to, and toxicological effects of, NPs are intimately associated with the processes that decide their environmental fate and behaviour. It is widely acknowledged that the composition, size, shape, and surface energy of NPs are key properties that determine the surface and speciation chemistry, stability and aggregation behaviour. Under certain conditions some core materials may react resulting in the transformation of the surface layer (e.g. sulpherisation of silver under reducing conditions (Choi et al., 2009) or alternatively surface entropy may favour the dissolution of the particle leading to the production of free metal ions (Puzyn et al., 2011). For particles that remain intact, it is known from classic Derjaguin-Landau and VerweyOverbeek (DLVO) theory that the stability of a colloidal dispersion is determined by the combined forces of the attractive Van der Waals forces and the repulsive energy of the surrounding electric double layer (Shaw, 1970). Additionally non-DLVO forces such as steric stabilization are known to affect dispersion stability (Baalousha et al., 2009). These properties themselves are affected by abiotic factors in the environment such as $\mathrm{pH}$ and the presence of organic matter, which can change electrostatic conditions in the media (e.g. ionic strength or $\mathrm{pH}$ ) or exert steric stabilization influencing fate and behaviour of NPs and as a result organism exposure (Christian, 2009; Bian et al., 2011; Baalousha et al., 2008; Handy et al., 2008).

Among the current range of NPs in production, ZnO NPs are already among the most widely used in cosmetics products and in some countries (not currently the EU) in sunscreens. ZnO NPs have been found to be some of the most harmful in aquatic exposures (Kahru \& Dubourguier, 2010) and have also been found to be toxic to soil living organisms (Kool et al. 2011, Dimkpa et al. 2011). Studies to date on the toxic effects of NPs towards earthworms have generally found that NPs are less toxic than equivalent ionic exposure (Unrine et al., 2010a; Coleman et al., 2010; Hooper et al., 2011). However, to date these studies have largely been conducted in standardised test media.

From studies conducted with trace metals, it is widely acknowledged that soil properties, such as soil $\mathrm{pH}$, can modify the bioavailability and toxicity of metals in soils systems. Soil $\mathrm{pH}$ is the most 
important soil property affecting $\mathrm{Zn}$ partitioning between the solid phase and the pore water. For NPs, the situation may be even more complex because not only will soil properties affect the speciation and availability of desorbed ions, but soil solution properties such as $\mathrm{pH}$, ionic strength and concentrations of humic substances will affect NP behaviour in a manner dependent on the intrinsic properties of the particle. For example, humic substances have been found to coat NP surfaces exerting stabilizing and destabilizing effects depending on the thickness and nature of the coating and media pH (Baalousha et al., 2008; Bian et al., 2011). Similarly pH has also been found to influences NP properties. Thus, decreasing $\mathrm{pH}$ has been found in water suspensions with $\mathrm{ZnO}$ nanoparticles (Dimkpa et al. 2011). To date, however, the relevance of such process to soil have yet to be investigated, identifying this topic as relevant to understanding the long-term behaviour of NP in the terrestrial compartment.

To understand how media properties influence $\mathrm{Zn}$ and $\mathrm{ZnO}$ behaviour, bioavailability and toxicity, comparative effects of nano, non-nano, and dissolved zinc need to be investigated in detail. Currently there is an absence of studies performed in natural soil and at different $\mathrm{pH}$ levels. To address this knowledge gap, this study investigates how soil $\mathrm{pH}$ affect the fate, behaviour and toxicity of three forms of zinc: 1) ionic zinc dosed as the chloride salt, 2) a $30 \mathrm{~nm} \mathrm{ZnO} \mathrm{NP} \mathrm{and} \mathrm{3)} \mathrm{a}$ larger non-nanoscale $\mathrm{ZnO}$ material. The following hypotheses are addressed within the study: First that $\mathrm{Zn}$ ions taken up from soil solution by the worms are primarily responsible for observed toxicity independent of exposure form . If this is the case, it can be expected that the toxicity of the ionic $\mathrm{Zn}$ and nano and non-nano $\mathrm{ZnO}$ will be greater at lower $\mathrm{pH}$ since $\mathrm{Zn}$ sorption to the soil and $\mathrm{ZnO}$ solubility will be negatively correlated with $\mathrm{pH}$. It would also be expected that toxicity will be independent of $\mathrm{Zn}$-form and $\mathrm{pH}$ when expressed according to dissolved $\mathrm{Zn}$ ion pore water concentrations. Further that $\mathrm{ZnO}$ will be more toxic than non nano scale $\mathrm{ZnO}$ when expressed on a Zn mass basis, since NPs have a larger surface area for ion desorbtion and greater surface reactivity than the bulk Zn. Finally that $\mathrm{Zn}$ accumulation into earthworm tissues is related to the soluble metal 
concentration and if compared on that basis will be independent of $\mathrm{Zn}$ form. Furthermore, in worms with similar total Zn burden, similar toxic effects would be anticipated.

\section{Materials and methods}

Soil

The test soil was collected from an open heathland site in Wareham forrest (Ordnance Survey Grid Reference: SU108058, Dorset, United Kingdom). The vegetation on site was dominated by heather (Erica sp.) with small trees. This soil was chosen for sampling because of its acidity (around $\mathrm{pH} 4$ ) which made it ideal for constituting a low $\mathrm{pH}$ treatment, while higher $\mathrm{pH}$ treatments could be obtained by soil ammendment to raise $\mathrm{pH}$. During sampling, large roots were removed, and soil was collected from 0-30 cm depth. The soil was homogenised, sieved through a $5 \mathrm{~mm}$ mesh and air dried (initial moisture content was approximately $14 \% \mathrm{w} / \mathrm{w}$ ).

From samples of the sieved dried material, texture (hydrometer method), $\mathrm{pH}$ (determined in water and $0.01 \mathrm{M} \mathrm{CaCl}{ }_{2}$ ), conductivity, total carbon and nitrogen (Dry combustion and Kjeldahl method respectively), cation exchange capacity (Kjeldahl method), along with oxalate and citratebicarbonate-dithionite (CBD) extractable iron and aluminium was determined according to standard operating procedures set out in Møberg et al. (1994) and Borggaard et al. (2003). A summary of the soil properties can be found in Table S1. Soil water holding capacity (WHC) was determined using a volumetric standard method (Rothamsted Research, 2011).

Soil pH adjustment

The exposures were conducted at a range of $\mathrm{pH}$ values encountered in natural soil solutions as selected based on the result of a UK national soil survey (Emmett et al., 2010). The sieved homogenised soil was divided into three batches of approximately $50 \mathrm{~kg}$ dry weight. To adjust the 
$\mathrm{pH}$ of the soil to three levels $0.2 \%, 0.45 \%$, and $1 \% \mathrm{w} / \mathrm{w}$ calcium carbonate $\left(\mathrm{CaCO}_{3}\right.$, Sigma Aldrich) was added to the soil (Table S2). These $\mathrm{pH}$ amendments gave values of $4.8,5.9$, and 7.2 (range $\pm 0.3 \mathrm{pH}$ units for 3 replicate samples in all cases) as measured in a 1:3 slurry of test soil made in distilled water. These are hereafter refered to as the low, medium and high $\mathrm{pH}$ soils, respectively. For each replicate, $450 \mathrm{~g}$ dry weight of the respective $\mathrm{pH}$ soil was added to the test container ( $1 \mathrm{lt}$ glass Kilner jars).

Chemicals

The $\mathrm{ZnO}$ based nanomaterial selected for this experiment was NanoSun zinc oxide P99/30 obtained from Microniser Pth Ltd (Dandenong, Australia) with a nominal average particle size of $30 \mathrm{~nm}$. The NanoSun P99/30 ZnO has no coatings or surface modifications and is a white odourless dry powder of particles with a close to spherical shape. The stated/nominal water solubility is $0.0016 \mathrm{~g} / \mathrm{l}$ at $20^{\circ} \mathrm{C}$, the melting point $1975^{\circ} \mathrm{C}$ and the purity $99.5 \%$. In addition to the NanoSun ZnO NP, two further Zn forms were studied. These were dissolved $\mathrm{Zn}^{2+}$ from $\mathrm{ZnCl}_{2}$ (BHDChemicals, Poole, UK) and a nonnano scale ZnO material also obtained from Microniser Pth Ltd. This non-nano scale ZnO powder had an average nominal primary particle size of $200 \mathrm{~nm}$, but was otherwise identical to the $30 \mathrm{~nm}$ material.

We verified the primary particle size reported by the manufacturer by TEM ( JEOL 2010 analytical TEM operating at 200kV). Results of particle size determination with different methods are collected in table S3. The hydrodynamic diameter of the particles in the stock suspension and the zeta potential were determined by Dynamic Light Scattering (DLS) and Laser Doppler Electrophoresis (LDE) respectively using a Malvern Zetasizer Nano ZS. Density measurements were carried out with a helium pycnometer (Micromeritics AccuPyc, model 1340). Specific surface area (SSA) of powders was measured by Brunauer-Emmett-Teller (BET) method (Micromeritics AccuPyc, model Gemini 2360). Having the specific surface area, and assuming that all particles were spherical and identical, the average diameter of the particles was calculated. X-ray diffraction (XRD) with a Philips X'pert Pro 
Diffractometer (PANalytical) was performed to confirm the NPs' crystallographic phase as ZnO. The solid powders were placed in sample holders at room temperature and analyzed with $\mathrm{Cu} \mathrm{Ka}$ radiation at 2 Theta angles from 10 to 100 with 0,03 o step. Particle size was determined by Scherrer equation. Stock solutions of all materials were prepared in equal $\mathrm{Zn}$ concentrations (nominal concentration $7.5 \mathrm{mg} \mathrm{Zn/ml),} \mathrm{taking} \mathrm{into} \mathrm{account} \mathrm{the} \mathrm{purity} \mathrm{of} \mathrm{the} \mathrm{materials} \mathrm{and} \mathrm{the} \mathrm{composition} \mathrm{of}$ the material.

Dosing procedure

Particles were dosed into the soils as a dispersion in a soil suspension made from each of the three $\mathrm{pH}$ soils to produce the required test concentrations in the test soil. This method is based on the dosing technique described by van der Ploeh et al. (2011) and adapted by Kool et al. (2011). The method was selected because the particles are introduced into the soil in a way that mimics their state in soil pore water. The soil suspensions were prepared by mixing air dried $\mathrm{CaCO}_{3}$ ammended Dorset soils with MilliQ water in a 1:2.5 soil:water ratio $(\mathrm{w} / \mathrm{v})$. The slurries were then shaken at 200 rpm at room temperature for 1 hour and then filtered through Whatmann No. 1 paper. The different $\mathrm{Zn}$ forms were then dispersed in the soil suspension to produce a highly concentrated stock dispersion/solution. The dispersions of nano $\mathrm{ZnO}$ and non-nano $\mathrm{ZnO}$ in the soil solution were then prepared for soil dosing following an established protocol (PROSPECT, 2010). Zn spiked suspensions were sonicated for 30 seconds in a sonication bath and then continously stirred before application to soils. Aliquots of unspiked and spiked soil suspensions were taken for immediate characterization and measurement of $\mathrm{pH}$, zeta potential and hydrodynamic radius. After dosing the soil, pure MilliQ water was added to all containers to reach appropriate soil moisture content ( $45 \%$ of maximum water holding capacity, WHC) in the test soils; his being within the recommended range of $40-60 \%$ WHC recommended by the OECD (2004) test guideline. The soils were then thoroughly mixed to ensure a homogeneous distribution of zinc through the soil. The freshly spiked soils were 
equilibrated for seven days before organism exposure. The control containers for all soil pH levels received MilliQ water only.

Experimental animals and toxicity test procedure

Eisenia fetida were initially obtained from Blade's Biological (Kent, UK) and reared in a sheltered outdoor culture consisting of a mix of clean horse manure and composted bark. Immediately prior to the test, adult worms with a well developed clitellum were collected from the cultures and acclimatised to the test temperature $\left(20 \pm 1^{\circ} \mathrm{C}\right)$ for 24 hours in a loamy soil with manure provided as food. The average weight of individual worms used was $0.36 \pm 0.03 g(S D, n=2100)$. The study was conducted using a procedure based on the OECD guideline 222 (OECD, 2004). The study comprised nine parallel similarly designed toxicity tests conducted with ZnO NPs, non nano scale ZnO and $\mathrm{ZnCl}_{2}$, each with a seperate test series for each material performed at each of the low, medium and high soil pH levels. The tests series with zinc chloride and nanoparticulate $\mathrm{ZnO}$ each had 6 exposure levels of $238,381,610,976,1520$, and $2500 \mathrm{mg} \mathrm{Zn/kg} \mathrm{dw} \mathrm{soil.} \mathrm{For} \mathrm{logistic} \mathrm{reasons,} \mathrm{the} \mathrm{non-nano}$ $\mathrm{ZnO}$ test was conducted using a reduced number of exposure levels of 381, 976 and $2500 \mathrm{mg} \mathrm{Zn/kg}$ dw soil. All treatments (i.e. each material at each tested concentration and soil $\mathrm{pH}$ ) had four replicates. The overall controls for the experiment comprised ten separate replicates per soil $\mathrm{pH}$ level. This gave a total of 210 containers in the full experiment.

For practical reasons the experiment was started over a period of ten days with all jars fully randomised. This meant that a maximum of 21 jars were handled per day at any stage. During the exposure, each replicate was fed $5 \mathrm{~g}$ dry weight of horse manure in two batches, with $2.5 \mathrm{~g}$ fed at the start and after two weeks of the experiment. The ratio of water and dry manure was $4: 1$ by weight. The food was placed in a small hole in the middle of the test soil as described by Van Gestel et al. (1989). 
For each replicate, 10 worms were collected from the preincubated culture. The worms were washed, blotted dry and weighed as a batch of ten before being put onto the surface of the test soil. The worms were incubated for 28 days at $20 \pm 1^{\circ} \mathrm{C}$ under constant light. Weekly the test containers were opened to aerate the test soils and add de-ionized water to correct for moisture loss. After four weeks the soils were hand sorted and the surviving worms collected and weighed as a batch. The worms were left over night to egest their gut contents on moist filterpaper according to Arnold \& Hodson (2007) after which they were frozen at $-18^{\circ} \mathrm{C}$. Due to batch variation within the worm cultures, some mortality was observed within some test containers at the end of the four week period. This mortality was not treatment (dose and $\mathrm{pH}$ ) related and occurred only in replicates prepared in days 4-8. Therefore, to avoid inclusion of data from worms that were not in adequate condition during the experiment, it was decided only to exclude results from affected containers to provide data for two replicates per treatment in all cases. For selected replicates, earthworm reproduction, expressed as number of cocoons/worm/week, was recorded by wet sieving the soil and retrieving earthworm cocoons. Retrieved cocoons were then inclubated in a $50 \mathrm{~g}$ sample of the corresponding contaminated soil and maintained at $20 \pm 1^{\circ} \mathrm{C}$ for four weeks, whereafter the total number juveniles alive in the soil were forced to the surface using a $60^{\circ} \mathrm{C}$ water bath and counted to allow juvenile production to be assessed as the product of cocoon production and hatching traits.

NP characterisation in soil suspensions

Particle size distribution and zeta potential of unspiked (control) and nano ZnO spiked soil suspensions were assessed using dynamic light scattering (DLS) (Zetasizer, Malvern Insruments Ltd, Malvern, UK). Samples of the nano $\mathrm{ZnO}$ dosed suspension were also prepared for transmission electron microscopy analysis by drying 1 drop on a TEM grid for 1 hour followed by examination on a JEOL 2010 analytical TEM equipped with Oxford Instruments LZ5 windowless energy dispersive X-ray spectrometer (EDS). 
Extraction of pore water from spiked soil

A separate soil sample of $200 \mathrm{~g}$ dry weight of soil of each $\mathrm{pH}$ was spiked with same quanities of the three $\mathrm{Zn}$ forms to give concentrations equivalent to the test treatments for all $\mathrm{ZnO}$ treatments and for three of the six $\mathrm{ZnCl}_{2}$ treatments $(381,987$, and $2500 \mathrm{mg} / \mathrm{kg}$ ). This single soil per treatment was used to enable the extraction of soil pore water to allow an an assessment of the influence of $\mathrm{pH}$ and $\mathrm{Zn}$ concentartion and form on $\mathrm{Zn}$ bioavailability at the beginning (day 0 ) of the experiment without impact on the replicate number of the main exposure. After an initial aging period following the same procedure as for the test soils, the soils were saturated with Milli Q water and left for 10 days to equilibrate. Subsequently the soil pore water was extracted by centrifugation (Beckman coulter Allegra $^{\mathrm{TM}} 25 \mathrm{R}$ Centrifuge) at 2,482 $\mathrm{g}$ for two hours, and the supernatant centrifuged at $18,330 \mathrm{~g}$ for a further hour to minimise the number of remaining soil particles. The total organic carbon content of the soil pore water was measured by DC-190 TOC-analyzer (Rosemount Analytical, Solon, USA) calibrated with a 1000 ppm sucrose solution in Milli Q water. Soil pore water was analysed for pH (measured in control soils and soils spiked at 235 and $2500 \mathrm{mg} / \mathrm{kg}$ nano $\mathrm{ZnO}$ ), zeta potential and size distribution (Zetasizer, Malvern Insruments Ltd, UK). For Zn concentrations analysis, the centrifuged soil pore water extracts were acidified by addition of $1 \mu \mathrm{l} / \mathrm{ml} 1 \mathrm{M}$ nitric acid and zinc concentration in the pore water analysed by Atomic Absorption Spectroscopy (AAS) (Perkin Elmer 1100B). After 56 days this procedure was repeated (excluding $\mathrm{pH}$ measuring and particle characterization), this time using a pooled sample comprising an equal quantity of soil taken from the test containers, to allow an assessment of the trends of $\mathrm{pH}$ and $\mathrm{Zn}$ treatment and form on water extractable zinc concentration and organic carbon content at the point at which juvenile production was assessed.

Metal analysis in soils, pore waters and earthworm tissues 
Approximately $100 \mathrm{mg}$ oven-dried soil samples from all considered experimental replicates in the test with $\mathrm{ZnO}$ materials and for three of the six $\mathrm{ZnCl}_{2}$ treatments $(381,987$, and $2500 \mathrm{mg} / \mathrm{kg}$ ) were used for analysis of total $\mathrm{Zn}$ concentrations. These samples were digested in $2 \mathrm{ml}$ of a 4:1 mixture of nitric acid (65\% p.a., Riedel-de-Haen, Seelze, Germany) and hydrochloric acid (37\% p.a., Baker, Grainger, USA) in tightly closed Teflon ${ }^{\circledast}$ bombs and oven heated at $140{ }^{\circ} \mathrm{C}$ for 7 hours. These digests were diluted with $8 \mathrm{ml}$ of $\mathrm{DI}$ water and total $\mathrm{Zn}$ measured by AAS (Perkin Elmer 1100B). A certified reference soil (International Soil-Analytical Exchange, WEPAL River clay, ISE sample 989, containing a certified concentration of $1060 \mathrm{mg} \mathrm{Zn/kg} \mathrm{dry} \mathrm{weight)} \mathrm{was} \mathrm{included} \mathrm{for} \mathrm{quality} \mathrm{control} \mathrm{purposes.} \mathrm{The}$ averages of measured $\mathrm{Zn}$ concentrations were within $99 \%$ of the certified reference value. No zinc was detected in the blank samples.

Tissue zinc concentrations were measured in three of the surviving earthworms for each replicate. For this analysis, worms depurated as described previously were lyophilisated and then digested using the same acid mixture and Teflon ${ }^{\circledR}$ bombs as for soil samples. Following digestion, samples were diluted with $6 \mathrm{ml}$ of distilled water to a total volume of $8 \mathrm{ml}$, to keep the analysed concentrations within calibration range and analysed for $\mathrm{Zn}$ concentration by AAS. Certified reference material (NRC Canada, DOLT-4, fish liver) was included in the analysis. The mean recovery of $\mathrm{Zn}$ was $100.1 \pm 0.36 \%$ from DOLT 4 .

Data handling

Metal data

Pore water $\mathrm{Zn}$ concentrations in the $\mathrm{ZnCl}_{2}$ treated soil for the measured treatments were used to estimate the remaining concentration for the unmeasured test concentrations using the Freundlich isotherm (Equation 1).

$$
C_{s}=K_{f} \cdot C_{p w}{ }^{n}
$$


Where $C_{s}$ is the zinc concentration in the soil $(\mathrm{mg} \mathrm{Zn} / \mathrm{kg}) ; K_{f}$ is the Freundlich sorption constant $(\mathrm{L} / \mathrm{kg}) ; C_{p w}$ is the zinc concentration in the pore water $(\mathrm{mg} \mathrm{Zn} / \mathrm{L})$, and $n$ is the shape parameter of the Freundlich isotherm.

\section{Toxicity data}

Concentration specific effects on the proportion of survivors, weight change as a percentage of initial weight and reproduction as cocoon production and juvenile production rates were analysed for each of the nine separate treatment series (i.e. three $\mathrm{Zn}$ types at three $\mathrm{pH}$ levels) were analysed using analysis of variance (ANOVA). Where significant differences were found the Tukey test was used to identify the pattern of significant differences between treatments (SPSS version 17). To estimate response parameters, data for survival and reproduction (cocoon and juvenile production rate) was used to fit a three parameter log logistic model (Equation 2) to obtain estimate $L C_{50}$ and/or $E C_{50}$ value.

$y=\frac{y_{\max }}{1+\exp \{b \cdot(\log (x)-\log (e))\}}$

Where $y_{\max }$ is the upper asymptote, $e$ is the concentration resulting in a $50 \%$ effect on the measured endpoint $\left(\mathrm{EC}_{50}\right)$ and $b$ the slope parameter. For the analysis of survival data, a binominal distribution of data within each treatment is assumed, while for weight change and reproduction, a normal distributions is assumed. Model fits to derive parameters with associated standard errors were completed using the drc package in R version 2.13.1 (R-project, 2011). All concentration response relationships were fitted using either measured total zinc in soil or pore water zinc concentrations.

\section{Bioaccumulation data}

Worm tissue Zn concentrations were analyzed using one-way ANOVA followed by Tukey test. Bioaccumulation factors (BAFs) for $\mathrm{Zn}$ were calculated by comparing measured tissue concentrations with measured total soil $\mathrm{Zn}$ concentrations in the soil. Since BAFs for metals such as $\mathrm{Zn}$ can tend to 
decrease at higher exposure levels especially when toxicity occurs (McGeer et al., 2003) BAF (and $\mathrm{BCF}$ ) values were only calculated for spiked treatments resulting in effect concentrations below $\mathrm{EC}_{50}$ for reproduction. Controls were also omitted, since bioavailability in the control soil was likely to be lower, and so not fully comparable, with the spiked soils (Hobbelen et al., 2006). Bioconcentration factors (BCFs) were calculated by comparing measured tissue concentrations with pore water $\mathrm{Zn}$ concentrations measured in the soil pore water.

\section{Results}

Material Characterization

TEM analysis indicated that the particles were spherical and relatively monodisperse in the case of NanoSunP99/30. The non nano scale material P99/200 contained a higher proportion of faceted rodshaped material . Characteristic images of the particles in distilled water and dosing solution are presented in the Supporting Information (Figure S1). The average primary particle diameters of the $\mathrm{ZnO}$ material batches as measured by TEM were $29.8 \mathrm{~nm} \pm 9.4$ (mean \pm standard deviation) for NanoSun $\mathrm{P} 99 / 30 \mathrm{ZnO}$ and $300 \mathrm{~nm} \pm 164$ (length) and $188 \mathrm{~nm} \pm 102$ (width) for non nano scale $\mathrm{ZnO}$ (Waalewijn-Kool et al. 2012). Crystallographic phase purity, crystallite size from XRD, grain size and specific surface area from BET measurements and Zeta potential in DI water, and density measurements are presented in Table S3.

Soil properties

The unadjusted Dorset soil was of sandy texture with a mean composition of $51.5 \%$ coarse sand, 40.2\% fine sand, $4.7 \%$ silt and $3.5 \%$ clay (Table S1). The soil had a low organic carbon content of $4 \%$ and a total nitrogen content of $0.13 \%$. The $\mathrm{pH}$ of the unadjusted soil was 4.2 when measured in $\mathrm{H}_{2} \mathrm{O}$ and 3.1 in $0.01 \mathrm{M} \mathrm{CaCl}_{2}$. Soil conductivity was $422 \mu \mathrm{S}$ and the maximum $\mathrm{WHC}$ was determined as 766 $\mathrm{ml} / \mathrm{kg}$ dry weight. 
Characterization in soil suspensions for dosing

The $\mathrm{pH}$ of the unspiked and nano $\mathrm{ZnO}$ dosed soil suspension used for the dosing of the NPs are shown in Table 1. Measurements of the soil suspensions indicated a rise of approximately one pH unit after dosing.

The zeta potential of unspiked soil suspensions is determined by the presence of natural colloids. Measurements indicated values between -10 and $-20 \mathrm{mV}$ (Table 1). These values indicate an potentially unstable dispersion of natural colloids in the suspension as the measured values did not differ greatly from a neutral charge (Baalousha et al., 2009). Only slight pH effects were observed, with the zeta potential being closest to the point of zero charge at higher $\mathrm{pH}$. Comparing spiked and unspiked soil suspensions, a positive shift in zeta potential towards the point of zero charge in the presence of NPs was observed at all pH levels. This indicates the likelihood of an unstable dispersion, with the particles likely to become agglomerated and settle out of suspension. Hence dosing suspensions were continuously stirred prior to spiking.

Average hydrodynamic sizes in the unspiked soil suspensions was over $1000 \mathrm{~nm}$, reflecting the presence of natural colloids. When ZnO NPs were added to the soil suspension for spiking, average particle size was reduced to $600-700 \mathrm{~nm}$. This analysis suggests the presence of an increased presence of particles and agglomerates smaller than the average hydrodynamic size of the natural colloids in solutions to which the ZnO NPs have been added. Size distribution by intensity in spiked samples showed a high degree of polydispersity in all the samples. Thus, DLS analysis indicated that the spiking solutions are dominated (on a mass basis) by the presence of larger structures within these high concentration dispersions. These may represent at least partly the presence of homoand/or hetero agglomerates of ZnO NPs with clays and humic substances. However, size distribution also confirmed the presence of NPs around or below $100 \mathrm{~nm}$. With regards to effects of soil $\mathrm{pH}$ on measured hydrodynamic radius in the soil suspensions, no significant effects were observed despite 
a slight tendency towards an increase in the number of smaller particles at higher pHs both in spiked and unspiked suspensions.

Particle imaging by TEM confirmed the DLS measurements showing ZnO NPs present primarily as hetero- and homo-agglomerates associated with organic material and NPs in the stock soil suspensions (Figure S3). Even though many particles were present as large agglomerates, a number of loosely associated small agglomerate and single particles were also present in the suspensions. TEM visual inspection provided no clear evidence of a trend for an effect of $\mathrm{pH}$ on the range of agglomerate sizes observed.

Total soil $\mathrm{Zn}$ and soil pore water $\mathrm{Zn}$ and organic carbon concentrations Recoveries of total $\mathrm{Zn}$ from the spiked soils ranged between 64 and 108\% (with an average recovery of $86 \%$ for all $\mathrm{Zn}$ forms). This confirms that actual concentrations were in close agreement with nominal values. Hereafter, within this article concentratration levels will be reffered to by their nominal concentration, although effect concentrations are in all cases calculated based on measured Zn concentrations.

The highest $\mathrm{Zn}$ pore water concentrations were measured in the $\mathrm{ZnCl}_{2}$ treated soils (Figure 1). These were in the range of 20 to 50 -fold higher than the pore water concentrations of $\mathrm{ZnO}$-spiked soils at the same nominated concentration. For all $\mathrm{Zn}$ forms, measured concentrations in the pore water increased with increasing nominal concentrations, ranging between 0.4 and $14.8 \mathrm{mg} / \mathrm{l}$ for nano $\mathrm{ZnO}$, between 0.7 and $14.4 \mathrm{mg} / \mathrm{l}$ for non nano $\mathrm{ZnO}$ and between 3.2 and $809 \mathrm{mg} / \mathrm{l}$ for $\mathrm{ZnCl}_{2}$ (Figure 1). Higher $\mathrm{Zn}$ pore water concentrations were found in the low $\mathrm{pH}$ soil for all $\mathrm{Zn}$ forms. After 56 days, zinc concentrations in the soil pore water were between $55-89 \%$ higher than initial measured values in the nano and non nano $\mathrm{ZnO}$ dosed soils especially at the high concentrations. This suggests a release of soluble $\mathrm{Zn}$ from the $\mathrm{ZnO}$ materials over the exposure period. The extracted soil pore water 
collected at Day 0 and Day 56 was analysed for total organic carbon content. At the later time point, pore water carbon concentrations were consistently lower than at the start of the experiment for samples taken from all treatment and $\mathrm{pH}$ levels (Figure S3). This may reflect a reduction in organic carbon solubility associated with factor such as the lower $\mathrm{pH}$ resulting as $\mathrm{Zn}^{2+}$ ions are liberated from dissolving $\mathrm{ZnO}$ particles.

Characterization of NP fate in soil pore water

To investigate the fate of the NPs in the soil and in particular on the supply of zinc ions to the labile pool and soil solution, soil pore water extracted from the NP spiked soils at a low ( $235 \mathrm{mg} \mathrm{Zn/kg}$ ) and a high (2500 mg Zn/ kg) Zn concentration were analysed using DLS (Table 2). A pH analysis of the soil pore water indicated that NP addition increased the $\mathrm{pH}$ in the low and medium $\mathrm{pH}$ treatments, but caused a small decrease at high $\mathrm{pH}$. These changes may be related to NP surface reactions consuming or liberating protons from the soil solution. Measurements at different $\mathrm{pH}$ values indicated that in soil solution there was a predominant negative NP surface charge which was largely independent of $\mathrm{pH}$. Size measurements indicated the presence of small $\mathrm{ZnO}$ agglomerates and/or a better dispersion of colloids in the soil solutions as compared to the highly concentrated spiking solutions.

Toxicity to E. fetida

Survival and weight change

Survival of Eisenia fetida was reduced in soils spiked with the highest concentrations of $\mathrm{ZnCl}_{2}$ at all $\mathrm{pH}$ levels. In contrast, effects on survival were less evident when worms were exposed to either nano or non-nano scale $\mathrm{ZnO}$ under any of the three soil $\mathrm{pH}$ regimes (Figure S4). For the ionic $\mathrm{Zn}$ exposures, a concentration response relationship was clearly evident at each soil $\mathrm{pH}$ and $\mathrm{LC}_{50}$ values of 718,590 and $1983 \mathrm{mg} \mathrm{Zn/kg}$ were estimated for $\mathrm{ZnCl}_{2}$ at the low, medium and high $\mathrm{pH}$ soils 
respectively (see Table 3). Non-nano $\mathrm{ZnO}$ had an effect on earthworm survival in the low and medium soil pHs. This effect could be described by a logistic model for the medium pH soil, although survival was not reduced below 50\%. At low pH a lower survival was found at $910 \mathrm{mg} / \mathrm{kg}$, however, this was not dose related. For earthworms exposed to ZnO NPs survival was only reduced compared to control in the high $\mathrm{pH}$ soil at $610 \mathrm{mg} / \mathrm{kg}$. This effect was not dose dependant since higher survival at higher ZnO NP concentrations was found. Weight change data generally confirmed the trends seen within the survival data. Thus, a dose related effects on weight loss was only observed in the $\mathrm{ZnCl}_{2}$ treated soils, but not in the $\mathrm{ZnO}$ spiked soils. Consequently since comparison between $\mathrm{Zn}$ forms is not feasible, these data were not dealt with any further.

\section{Reproduction}

Cocoon production was reduced in Eisenia fetida in a dose dependent manner by all three zinc forms and in each case for all of the soil pHs tested (Figure 2). This shows that reproduction is a more sensitive endpoint than survival for earthworm exposed to $\mathrm{ZnO}$, since effects on survival were not seen for these materials. Juvenile production data confirmed trends seen for cocoon production, hence these responses can be seen as effectively equivalent suggesting no $\mathrm{Zn}$ specific effects on cocoon viability.

Based on the cocoon production data (n.b. calculations using juvenile data would produce similar results), $\mathrm{EC}_{50}$ values for all $\mathrm{Zn}$ forms and soil $\mathrm{pH}$ values could be calculated from both measured total soil and soil pore water $\mathrm{Zn}$ concentrations (Table 4). When calculated using total soil Zn, a clear difference between estimated $\mathrm{EC}_{50}$ values for the ionic and the two particulate $\mathrm{ZnO}$ forms was evident. Ionic metal was approximately 2.5 fold more toxic than the particulate material. The comparison between the nano and non-nano $\mathrm{ZnO}$ indicated that these two forms gave comparable toxicity values. This suggests there is no strong particle size specific effect on $\mathrm{ZnO}$ toxicity within this test system. The influence of $\mathrm{pH}$ on toxicity was broadly consistent across all three $\mathrm{Zn}$ forms. The 
$\mathrm{EC}_{50}$ value based on total $\mathrm{Zn}$ concentrations in the high $\mathrm{pH}$ soil being higher than those in the medium and low pH soil. The trend was particularly evident in the ionic and ZnO NP tests (Table 4).

When cocoon production effect concentrations were calculated based on soil pore water $\mathrm{Zn}$ concentrations, $\mathrm{EC}_{50}$ values showed different trends than values estimated from total soil $\mathrm{Zn}$ levels. Thus, pore water $\mathrm{EC}_{50}$ values were up to three-fold lower for both $\mathrm{ZnO}$ compounds compared than values in the $\mathrm{ZnCl}_{2}$ test (Table 4). Again the toxicity of both $\mathrm{ZnO}$ forms are broadly comparable providing no indication of size specific toxicity. A clear effect of $\mathrm{pH}$ on $\mathrm{Zn}$ toxicity for all three $\mathrm{Zn}$ forms was also observed for the pore water $\mathrm{Zn}$ calculated values. The $\mathrm{EC}_{50}$ values found in the low $\mathrm{pH}$ soils generally being higher than those in the medium and high $\mathrm{pH}$ soils; the only exception being nano $\mathrm{ZnO}$ in the high $\mathrm{pH}$ soil (Table 4).

Zinc bioaccumulation and bioconcentration

Figure 3 displays the average internal Zn concentrations measured in Eisenia fetida after the 28 day exposure. Internal Zn concentrations measured in the control earthworms ranged between 100-200 $\mu \mathrm{g} / \mathrm{g}$ dry weight and were on average $132 \pm 13,123 \pm 2$ and $124 \pm 0.4 \mu \mathrm{g} / \mathrm{g}$ dry weight for the low, medium and high $\mathrm{pH}$ soil respectively. This is in good agreement with previous values (Lock \& Janssen, 2001). Tissue Zn concentrations were significantly dependent on $\mathrm{Zn}$ form (ANOVA, $p<0.05$ ). Post-hoc analysis indicated that earthworms exposed to nano and non-nano ZnO had significantly higher tissue $\mathrm{Zn}$ concentrations than the $\mathrm{ZnCl}_{2}$ exposed worms (Tukey, $\mathrm{p}<0.05$ ). Indeed the highest average internal concentrations were observed for worms exposed to non nano $\mathrm{ZnO}$ in the low $\mathrm{pH}$ soil spiked at $2500 \mathrm{mg} / \mathrm{kg}$ d.w.

In all treatments except the low pH ionic $\mathrm{Zn}$ test, a significant effects of exposure concentration on internal $\mathrm{Zn}$ concentration was found (ANOVA, $\mathrm{p}<0.05$ ). Post-hoc testing indicated a number of exposure concentrations were significantly different from controls predominantly at the higher test 
concentrations (see Figure 3). Based on the total zinc concentrations measured in the soil or pore water and the internal zinc concentrations, bioaccumulation factors using total $\mathrm{Zn}$ and bioconcentration factors using pore water $\mathrm{Zn}$ were calculated (Table 5). BAFs estimated for control worms were on average $33.2 \pm 7.05,28.8 \pm 0.87$ and $24.1 \pm 1.09$ for the low, medium and high $\mathrm{pH}$ soil, respectively. All BAFs for spiked soils (estimated as explained in material and methods) were below one, suggesting that as an essential metal, $\mathrm{Zn}$ can be excluded or regulated by earthworms. Analysis of the calculated bioaccumulation factors indicated a significant effect of $\mathrm{pH}$, with BAFs significantly lower in the high $\mathrm{pH}$ soil when compared to the low and medium $\mathrm{pH}$ treatements (one way ANOVA, $p<0.05)$. No significant effect of $Z n$ type on BAF was, however, evident. BCFs were also found to be significantly dependent on soil $\mathrm{pH}$ (one way ANOVA, $\mathrm{p}<0.05$ ). Highest BCFs were found at the high soil pH level. Differences in BCFs for the different Zn compounds were aparent across the experiment with the $\mathrm{BCF}$ being lower for $\mathrm{ZnCl}_{2}$ than the $\mathrm{ZnO}$ forms which in turn were comparable. Within each soil $\mathrm{pH}$, this trend was significant only in the low $\mathrm{pH}$ soil. This suggests that $\mathrm{Zn}$ uptake is not solely related to soluble $\mathrm{Zn}$ concentration in pore water, since if this was the case, an effect of $\mathrm{Zn}$ form would not be expected in any soil.

\section{Discussion}

This study is, to our knowledge, the first assessment of comparative toxic effects of dissolved $\mathrm{Zn}^{2+}$ $\left(\mathrm{ZnCl}_{2}\right), \mathrm{NP} \mathrm{ZnO}$ and nonnano $\mathrm{ZnO}$ to earthworms in a natural soil and also one of the few studies to explicitly incorporate the influence of soil $\mathrm{pH}$. The toxicity tests were combined with particle characterization techniques and supporting soil and tissue metal analysis to comprehensively assess the exposure scenario, fate, and availability of the ionic $\mathrm{Zn}$ and $\mathrm{ZnO}$ form in the soil at three different soil pHs tested.

Characterizarion of NPs in soil suspension and pore water 
NPs were characterized in the spiked soil suspensions used for dosing to assess the exposure scenario and determine the effect of the different $\mathrm{pHs}$. In the unspiked solution, soil pH affected the natural colloidal particles that were present within the extracted soil suspensions. Average size changed from $2000 \mathrm{~mm}$ to $1500 \mathrm{~mm}$ and zeta potential from -16 to -12 between the $\mathrm{pH} 5.1$ and 8 soils. In the $\mathrm{ZnO}$ spiked solutions zeta potential was near neutral regardless of $\mathrm{pH}$ (Table 1). At the observed $\mathrm{pH}$ range (Table 1 ), $\mathrm{ZnO}$ would be expected to have neutral ranging to negative zeta potential (Geert Conelis, personal communication) The absence of $\mathrm{pH}$ specifiic effects on zeta potential did not correlate with expections derived from DLVO theory (Shaw, 1970). Natural organic matter tends to coat the surface of environmental and manufactured NPs (Baalousha et al., 2009; Fabrega et al., 2009). When particles are coated with organic matter, charge neutralization can occur (Ghosh et al. 2009). Indeed Bian et al. (2011) tested the role of humic acids on the aggregation of ZnO NPs and reported that lower humic acid concentrations $(1.7 \mathrm{mg} / \mathrm{L})$ resulted in a higher sedimentation rate compared to suspensions without humic acid and attributed this effect to charge neutralization by adsorption of humic acids. Since the present study were conducted across a similar $\mathrm{pH}$ range $(6.2-8$, as compared to the circumneutral $\mathrm{pH}$ used from Bian et al. (2011)), such charge neutralisation can be expected to have occurred in the present study given that natural organic matter is present in the soil suspension. Indeed TEM images confirm that the ZnO NPs are associated with organic matter in the soil suspension (Figure S2), as also reported previously (Kool et al., 2011).

To provide exposure characterisation and assess the fate of the NPs in the soil after spiking, particle characterization was performed in pore water extracted from the NP spiked soils (Table 2). Measurement of particle size distributions and zeta potentials (of natural NPs and possibly ZnO NPs) were in agreement and accorded to DLVO theory and a dependence on $\mathrm{pH}$. Further dissolved zinc in the soil pore water can affect the surface charge of natural colloids by forming organo-metallic complexes (Tipping et al., 2003). This is a further considerations that might account for the changes 
in zeta potential and particles sizes observed in the the extracted pore water. The DLS measurements made, at exposure start indicated small $\mathrm{ZnO}$ agglomerates, however it could not be confirmed to what extent well disperse ZnO NPs were present in the extracted pore water. The total amount of zinc measured, demonstrated that the dosing did provide good uniform $\mathrm{pH}$ and $\mathrm{Zn}$ form dependent gradients of $\mathrm{Zn}$ in the pore water.

Fate and availability of zinc

To assess zinc and $\mathrm{ZnO}$ fate and availabillity under the three $\mathrm{pH}$ regimes, total zinc and dissolved carbon was measured in soil pore water extracts. Pore water carbon concentrations were found to decrease over the 56 day course of the experiment (Figure S3). Kalbitz et al. (2000) reported a complex relationship between $\mathrm{DOC}$ and soil $\mathrm{pH}$, however, it was concluded that generally $\mathrm{DOC}$ solubility is reduced at lower pHs. Analysis of the soil $\mathrm{pH}$ in the present study indicated a general drop in soil DOC over the 56 days exposure, across both soil $\mathrm{pH}$ and $\mathrm{Zn}$ dose. For example, at the top concentrations $(2500 \mathrm{mg} / \mathrm{kg})$, pH was reduced by between 0.5 and $1.2 \mathrm{pH}$ units, to 5.4 and 5.9 , in the medium and high $\mathrm{pH}$ soils respectively (related possibly to $\mathrm{CaCO}_{3}$ speciation and/or earthworm activity). This general pH shift could explain the decreasing concentration of total carbon observed in the extracted soil pore water between the start of the exposure and day 56.

The amount of total zinc in pore water extracted from the soil, was negatively correlated to soil pH, with the low pH soils ( $\mathrm{pH} 4.5$ ) having the highest pore water $\mathrm{Zn}$ concentrations. Although the trends seen here were based on analysis of a pooled soil samples for each treatment, similar trend have been observed in relation to the effects of $\mathrm{pH}$ on $\mathrm{ZnO}$ toxicity for springtails (P. Kools. et al submited) supporting the validity of our analysis. Further, a similar correlation was also found by Tipping et al. (2003) who found higher soil solution concentrations in lower pH field soils when compared to more neutral systems providing support for our observation. For $\mathrm{ZnO}$, a higher $\mathrm{Zn}$ concentration in solution can generally be expected below pH 6 compared to $\mathrm{pH}$ 6-9 as a result of both increased $\mathrm{ZnO}$ 
dissolution and $\mathrm{pH}$ influences on $\mathrm{Zn}$ solubility (Yamabi \& Imai, 2002). At low pH, soluble ionic forms will include $\mathrm{Zn}^{2+}$ and $\mathrm{Zn}(\mathrm{OH})^{+}$. However, between $\mathrm{pH} 6-9$, it is expected that solid $\mathrm{Zn}(\mathrm{OH})_{2}$ will precipitate from solution (Yamabi \& Imai, 2002). This speciation behaviour can explain the trends observed in this study where higher soluble $\mathrm{Zn}$ concentrations were found particularly in the low $\mathrm{pH}$ soil. Bian et al. (2011) observed the lowest dissolution of ZnO NPs within the pH 6-9 range. A finding similar to that observed in the present study for which lowest pore water concentrations were observed in the $7.2 \mathrm{pH}$ soil (Fig. 1).

In this study there was no obvious difference, in terms of dissolution and resulting soluble $\mathrm{Zn}$ concentrations between the ZnO NPs and non-nano scale ZnO. The same trend was found by Milani et al. (2010). Over the exposure time, zinc concentrations in the extracted pore water from the nano and non nano $\mathrm{ZnO}$ treated soils decreased slightly over time in both the low and high $\mathrm{pH}$ soils, but conversely increased at medium $\mathrm{pH}$. Reductions in soluble $\mathrm{Zn}$ at low $\mathrm{pH}$ can be attributed to the well known processes of aging which in turn act to increase the non-labile fraction. The increased solubility in the medium pH soil may be related to the decrease in the $\mathrm{pH}$ from 5.9 to 5.4 of this soil. This $\mathrm{pH}$ shift is unfavourable for the production of $\mathrm{Zn}(\mathrm{OH})_{2}$ precipitate forms, with possible consequences for soluble $\mathrm{Zn}$ concentrations.

\section{Toxicity to E. fetida}

Survival and reproduction of the control worms among included replicates generally meets the validity criteria of the OECD standard test protocol (OECD, 2004). The survival in controls overall was $98 \%$, reflecting the loss of only two worms in a single low $\mathrm{pH}$ control replicate. The average number of cocoons in the controls for the low, medium, and high pHs were $28.7 \pm 3.5,37.3 \pm 6.7$ and $36 \pm 7.5$ cocoons/container, respectively. These values are close to or exceed the validity criteria of $\geq 30$ juveniles per control as defined by the standard test guidelines (OECD, 2004). The cocoon production rates are also in agreement with results from other studies using the same earthworm 
species (e.g. Spurgeon et al., 2000; Spurgeon \& Hopkins, 1996a). Across the soils, cocoon production was lowest in the low pH soil. This suggests that $\mathrm{pH}$ itself acts as a mild stressor in the test. This effect was anticipated since the lowest $\mathrm{pH}$ used (4.8) is close to the limit of the normal biological pH range for E. fetida (Edwards \& Bohlen, 1996). The presence of a direct $\mathrm{pH}$ effect on reproduction is also consistent with results of previous studies of $\mathrm{pH}$ effects on earthworm reproduction and $\mathrm{Zn}$ toxicity (e.g. Spurgeon \& Hopkins, 1996a).

As anticipated, $\mathrm{ZnCl}_{2}$ had a clear negative impact on the survival and reproduction of $E$. fetida exposed to concentrations comparable to those known to be toxic for earthworms (e.g. Spurgeon and Hopkin, 1996a; Spurgeon et al., 1994; van Gestel et al., 1993). For example, Spurgeon et al. (1994) found an $\mathrm{LC}_{50}$ value of $1010 \mathrm{mg} / \mathrm{kg}$ for 14 days zinc exposure of E. fetida. While in the present study, $\mathrm{LC}_{50}$ values for $\mathrm{ZnCl}_{2}$ based on total soil $\mathrm{Zn}$ increased from 700 to $2000 \mathrm{mg} \mathrm{Zn} / \mathrm{kg}$ with increasing $\mathrm{pH}$ (Table 3). For both $\mathrm{ZnO}$ form, a lower toxicity was found when compared to ionic $\mathrm{Zn}$ with $\mathrm{LC}_{50}$ values being above approximately $2000 \mathrm{mg} / \mathrm{kg}$ for all soil $\mathrm{pHs}$. These results indicate a lower lethality from NP and non nano $\mathrm{ZnO}$ compared to $\mathrm{ZnCl}_{2}$ when evaluated based on total $\mathrm{Zn}$ concentrations. The same trend has also been found in other studies on metal based NPs (Hooper et al., 2011; Unrine et al., 2010a).

Reproduction rate was the most sensitive of the life-cycle endpoints studied, being significantly affected by all $\mathrm{Zn}$ forms in all soils tested (Table 4). Based on total soil Zn concentrations, highest toxicity was observed in the $\mathrm{ZnCl}_{2}$ treatment at low $\mathrm{pH}\left(\mathrm{EC}_{50}: 420 \mathrm{mg} \mathrm{Zn} / \mathrm{kg}\right.$ ). This compares compared to a $\mathrm{Zn} \mathrm{EC} 50$ value of $919 \mathrm{mg} / \mathrm{kg}$ for $\mathrm{ZnO} \mathrm{NPs}$ and $985 \mathrm{mg} / \mathrm{kg}$ for non-nano $\mathrm{ZnO}$ in the same soil. As for effects on survival, the lower reproductive toxicity of NP and non-nano scale materials when compared to the ionic form is in agreement with previous results (Hooper et al., 2011; Unrine et al., 2010b). For example, Hooper et al. (2011) found that Eisenia veneta 
reproduction after 21 days exposure to $750 \mathrm{mg} / \mathrm{kg}$ of $\mathrm{ZnO} \mathrm{NPs}(<-100 \mathrm{~nm})$ was reduced by $50 \%$, while the matching the total $\mathrm{Zn}$ concentration of $\mathrm{ZnCl}_{2}$ completely inhibited cocoon production.

Across all $\mathrm{Zn}$ forms, observed toxic effects were found to be influenced by soil $\mathrm{pH}$. When effect concentrations were derived based on total soil $\mathrm{Zn}$ levels, the tendency was for higher toxicity (i.e. lower effect concentrations) at lower $\mathrm{pH}$. This $\mathrm{pH}$ effect can be explained by the higher $\mathrm{Zn}$ availabillity resulting from the increased solubility of the $\mathrm{Zn}$ at low $\mathrm{pH}$ values. When effect concentrations were calculated based on pore water $\mathrm{Zn}$ concentrations, this relationship with $\mathrm{pH}$ was reversed. Thus, the lowest pore water based effect concentrations, indicative of higher toxicity were observed in the high $\mathrm{pH}$ for ionic $\mathrm{Zn}$ and the non-nano scale material and at the medium $\mathrm{pH}$ for ZnO NPs. According to the biotic ligand model (Paquin et al., 2002; Santore et al., 2002), low pH is characterised by a high concentration of $\mathrm{H}^{+}$ions and a resulting high competition between $\mathrm{Zn}^{2+}$ and other cations, most notably $\mathrm{H}^{+}$, in soil solution for binding to key organisms receptors. That the relationship between effect concentrations derived from soluble $\mathrm{Zn}$ levels and soil $\mathrm{pH}$ follows similar trends, suggests ionic Zn governs a large part of the toxicity caused, and confirms the importance of considering existing paradigms of metal toxicity with NP effect assessment (van Gestel et al. 2010).

While in some respects toxicity followed ion based paradigms as above, then comparing $\mathrm{EC}_{50} \mathrm{~S}$ calculated based on pore water $\mathrm{Zn}$ concentration between $\mathrm{Zn}$ forms indicated that both NP and nonnano $\mathrm{ZnO}$ generally produced greater effect at lower soluble concentration than for ionic $\mathrm{Zn}$ (Figure 3). These results suggest a complex relationship between toxicity and soluble $\mathrm{Zn}$ concentration for particulate forms of zinc, that cannot be related to $\mathrm{Zn}$ ion derived toxicity only. It has been suggested that metal based NPs, such as ZnO NPs, can cause a high localised exposure of toxic dissolved species, since the concentration of ions close to the particle surface will be greater than in the bulk solution (Apte et al. 2009). Such localised NP specific effects could explain the high toxicity for the $\mathrm{ZnO}$ forms. A further mechanism of NP toxicity that can result in nano specific toxic effects can occur via the formation of reactive oxygen species (ROS). Dimkpa et al. (2011) observed that association of 
$\mathrm{Cu}$ and ZnO NPs with soil bacterial cells, led to an accumulation of ROS on the inside of the cell and resulting dysfunction. Since the $\mathrm{ZnO}$, either as well dispersed material or as agglomerates, can be expected in the soil solution and so come into contact with body surfaces, this mechanism can potentially explain the higher $\mathrm{ZnO}$ toxicity based on zinc pore water concentrations. The endocytosis of these surface associated particles can also lead to uptake with the further potential for greater toxicity resulting from local hotspots (Apte et al., 2009).

Zinc bioaccumulation and bioconcentration

Bioaccumulation factors (BAFs) for the three $\mathrm{Zn}$ forms were all in the range reported for zinc by Suthar \& Singh (2009) for E. fetida. All BAFs were below one indicating that biomagnification of Zn does not occur under the conditions tested. This is in good agreement with the fact that zinc is an essential metal and is highly regulated by earthworms (Spurgeon and Hopkin, 1996b, Lock \& Janssen, 2001; Hobbelen et al., 2006). For example, Lock \& Janssen (2001) found that internal Zn concentrations were frequently regulated to a level between $100-200 \mathrm{mg} / \mathrm{kg}$ by earthworms. An observation that corresponds well with the findings of the current study at low soil Zn levels. Indeed for $\mathrm{ZnCl}_{2}$ only in some of the higest $\mathrm{Zn}$ concentrations did internal zinc concentrations differ significantly from the control. While for both forms of $\mathrm{ZnO}$ a more general trend of significant increases in internal $\mathrm{Zn}$ concentrations were observed at lower concentrations (Figure 4).

Comparisons between the BAFs (calculated relative to total soil $\mathrm{Zn}$ ) and BCF (calculated by relation to pore water soluble $\mathrm{Zn}$ ) for the different $\mathrm{Zn}$ forms indicated higher values in worms exposed to $\mathrm{ZnO}$ (as either NP or non-nano form) than for worms exposed to $\mathrm{ZnCl}_{2}$ when exposed to similar total Zn concentrations (Fig. 4). Hooper et al. (2011) also noted a similar trend for increased internal concentration, but lower toxicity in Eisenia veneta exposed to a ZnO NP. Such increase accumulation in $\mathrm{ZnO}$ exposed earthworms may be related to the presence of internalised particles (Unrine et al., 2010b; Hooper et al., 2011). For example, crystaline ZnO was detected in E. veneta tissue after an 
aqueous ZnO NP exposure (Hooper et al., 2011). Taken together, these data suggest that the fundamental paradigm of a link between body burden and toxic effect that is inherent in models such as the critical body residue hypothesis (which assume a direct relationship between internal concentration and effect) could be more complex for ZnO NPs than is the case for ionic metal or indeed other chemicals. However, the fact that the same trend for increased internal concentration was seen for both $\mathrm{ZnO}$ forms suggests that this increased assimilation is not a nano size specifc effect, but more likely related to $\mathrm{Zn}$ ion availability, delivery and resupply in the pore water phase.

\section{Conclusion}

The comparative toxic effects of dissolved $\mathrm{Zn}\left(\mathrm{ZnCl}_{2}\right)$, nano $\mathrm{ZnO}$ and non nano scale $\mathrm{ZnO}$ to the earthworm Eisenia fetida has been thoroughly investigated in natural soil at three different soil pHs. Particle characterization in spiked soil suspension and extracted pore water indicated changes in zeta potential, size distributions and soluble $\mathrm{Zn}$ concentrations that reflect the interactions of the different $\mathrm{Zn}$ form with soil constituents under the range of tested soil $\mathrm{pH}$ conditions. Based on the characterisation and toxicity data obtained it was possible to test the three hypotheses set out previously: First that $\mathrm{Zn}$ ions taken up from soil solution by the worms are primarily responsible for observed toxicity independent of exposure form. This hypothesis was partly validated, since greatest toxicity was found at low $\mathrm{pH}$ where particle disolution can be expected. However, interestingly calculation of effect concentration based on pore water $\mathrm{Zn}$ concentrations indicated lower values in the $\mathrm{ZnO}$ test. This suggest the presence of a particle specific toxicity in tests conducted with these materials. Our second hypothesis was that $\mathrm{ZnO}$ would be more toxic than non-nano $\mathrm{ZnO}$ when expressed on a total $\mathrm{Zn}$ mass basis, due to factors such as increased dissolution and greater surface reactivity. In this case we were not able to find evidence supporting this ascertion. Thus for the $\mathrm{ZnO}$ materials considered ( $30 \mathrm{~nm}$ vs $200 \mathrm{~nm}$ ) similar solubility relationships with $\mathrm{pH}$, toxicity and bioaccumulation patterns were found. Finally we assessed how accumulation into body tissue were 
related to the soluble concentration and toxicity. Contrary to our expectation body burdens were higher in $\mathrm{ZnO}$ exposed worm than worms exposed to $\mathrm{ZnCl}_{2}$, even though toxicity was greatest for the ionic form. These results suggest the importance of carefully considering the relationship between uptake and toxicity in future nanotoxicology studies.

URL: http://mc.manuscriptcentral.com/tnan 
1

2

3

4

5

6

7

8

9

10

11

12

13

14

15

16

17

18

19

20

21

22

23

24

25

26

27

28

29

30

31

32

33

34

35

36

37

38

39

40

41

42

43

44

45

46

47

48

49

50

51

52

53

54

55

56

57

58

59

60

\section{Acknowledgements}

The authors would like to acknowledge Rudo A. Verweij at the Vrije University of Amsterdam, for help and guidance with metal analysis and Birgitte Boje Rasmussen at the University of Copenhagen for performing soil characterization analysis. The RECETO Ph.D. school are acknowledged for additional funding of Miss L. R. Heggelund via the RECETO Scolar Stipend. Dr. M. Diez-Ortiz is supported by a Marie Curie Intra-European Fellowship within the 7th European Community Framework Programme (call reference FP7-PEOPLE-2010-IEF, 273207 Nano-Ecotoxicity). The NanoFATE, Project CP-FP 247739 (2010-2014) under the 7th Framework Programme of the European Commission (FP7-NMP-ENV-2009, Theme 4), coordinated by C. Svendsen; www.nanofate.eu is acknoweldge for financial support. 


\section{References}

Apte SC, Rogers NL, Batley GE. (2009). Ecotoxicology of Manufactured NPs. In Lead \& Smith Blackwell publishing Ltd..

Arnold RE \& Hodson ME. 2007. Effect of time and mode of depuration on tissue copper concentrations of the earthworms Eisenia andrei, Lumbricus rubellus and Lumbricus terrestris. Environ Pollut 148(1): 21-30.

Baalousha M, Lead JR, von der Kammer F, Hofman T. (2009). Natural Colloids and NPs in Aquatic and Terrestrial Environments. In Lead \& Smith Blackwell Publishing Ltd.: 109-147.

Baalousha M, Mancuilea A, Cumberland S, Kendall K, Lead JR. 2008. Aggregations and surface properties of ions oxide NPs: influence of $\mathrm{pH}$ and natural organic matter. Environ Toxicol Chem, 27, 9: $1875-2008$.

Benn TM \& Westerhoff P. 2008. NP silver released into water from commercially available sock fabrics. Environ Sci Technol 42: 4133-9.

Bian S, Mudunkotuwa IA, Rupasinghe T, Grassain, VH. 2011. Aggregation and Dissolution of $4 \mathrm{~nm}$ ZnO NPs in Aqueous Environments: Influence of pH, lonic Strength, Size, and Adsorption of Humic Acid. Langmuir 27: 6059-6068.

Borggaard OK, Gimsing AL \& Klünder MH. 2003. Laboratorieøvelser i jordbundslære - Vejledning. Samfundslitteratur, KVL-bogladen. 
Christian P. (2009). Nanomaterials: Properties, Preparation and Applications. In Lead \& Smith, Blackwell Publishing Ltd., 31-73.

Coleman J G, Johnson D R, Stanley JK, Bednar AL, Weiss CA, Boyd RE, Stevens JA. 2010. Assessing the fate and effects of nano aluminum oxide in the terrestrial earthworm, Eisenia fetida. Environ Toxicol Chem, 29, 7: 1575-1580.

Choi Okkyoung, Clevenger TE, Deng B, Surampalli RY, Ross Lr, Hu Z. 2009. Role of sulfide and ligand strength in controlling nanosilver toxicity. Water Res, 43, 7: 1879-1886

Dimkpa CO, Calder A, Britt DW, McLean JE, Anderson A J. 2011. Responses of a soil bacterium, Pseudomonas Chlororaphis 06 to commercial metal oxide NPs compared with responses to metal ions. Environ Pollut, 159: 1749-1756.

Edwards C A \& Bohlen PJ. (1996). Biology and ecology of earthworms. Springer.

Emmett BA, Reynolds B, Chamberlain PM, Rowe E, Spurgeon D, Brittain SA, Frogbrook Z, Hughes S, Lawlor AJ, Poskitt J, Potter E, Robinson DA, Scott A, Wood C, Woods C. 2010. Countryside Survey: Soils Report from 2007. NERC Centre for Ecology and Hydrology, CS Technical Report No. 9/07, Wallingford, UK.

Fabrega J, Fawcett SR, Renshaw JC, Lead JR. 2009. Silver NP impact on bacterial growth: Effect of pH, concentration, and organic matter. Environ Sci Technol, 43, 19: 7285-7290.

Ghosh S, Mashayekhi H, Bhowmik P, Xing B. 2009. Colloidal stability of $\mathrm{Al}_{2} \mathrm{O}_{3}$ NPs as affected by coating of ctructurally different humic acids. Langmuir, 26, 2: 873-879. 
Gottschalk F, Sonderer T, Scholz R, Nowack B. 2009. Modeled environmental concentrations of engineered nanomaterials ( $\mathrm{TiO}_{2}, \mathrm{ZnO}, \mathrm{Ag}, \mathrm{CNT}$, Fullerenes) for different regions. Environ Sci Technol, 43: 9216-9222.

Handy RD, von der Kammer F, Lead JR, Hassellöv M, Owen R, Crane M. 2008. The ecotoxicity and chemistry of manufactured NPs. Ecotoxic, 17: 278-374.

Hobbelen PHF, Koolhaas JE \& van Gestel CAM. 2006. Bioaccumulation of heavy metals in the earthworms Lumbricus rubellus and Aporrectodea caliginosa in relation to total and available metal concentrations in field soils. Environ Pollut, 144, 2: 639-646.

Hooper HL, Jurkschat K, Morgan AJ, Bailey J, Lawlor AJ, Spurgeon DJ, Svendsen C. 2011. Comparative chronic toxicity of NPs and dissolved zinc to the earthworm Eisenia veneta in a soil matrix. Environ International, 37: 1111-1117.

Johnson A C, Bowes MJ, Crossley A, Jarvie HP, Jurkschat K, Jürgens M, Lawlor AL, Park B, Rowland P, Spurgeon D, Svendsen C, Thompson IP, Barnes RJ, Williams RJ. 2011. An assessment of the fate, behavior and environmental risk associated with sunscreen $\mathrm{TiO}_{2} \mathrm{NPs}$ in UK field scenarios. Sci Total Environ, 409: 2503-2510.

Kahru A. \& Dubourguier H. 2010. From Ecotoxicology to nanoecotoxicology. Toxicology, 269: 105119.

Kalbitz K, Solinger S, Park JH, Michalzik B, Matzner E. 2000. Controls on the dynamics of the dissolved organic matter in soils: A review. Soil Sci, 165, 4: 277-304. 
Kool PL, Diez-Ortiz M \& van Gestel CAM. 2011. Chronic toxicity of $\mathrm{ZnO} N P s$, non-nano $\mathrm{ZnO}$ and $\mathrm{ZnCl}_{2}$ to Folsomia candida (Collembola) in relation to bioavailability in soil. Environ Pollut, 159: 2713-2719.

Lock K \& Janssen CR. 2001. Comparative toxicity of a zinc salt, zinc powder and zinc oxide to Eisenia fetida, Enchytraeus albidus and Folsomia candida. Chemosphere, 53: 851-856.

McGeer JC, Brix KV, Skeaf JM, DeForest DK, Brigham SI, Adams WJ \& Green A. 2003. Inverse relationship between bioconcentration factor and exposure concentration for metals: implications for hazard assessment of metals in the aquatic environment. Environ Toxicol Chem, 22, 5: 10171037.

Milani N, McLaughlin MJ, Hettiaratchchi GM, Beak DG, Kirby JK, Stacey S. 2010. Fate of nanoparticulate zinc oxide fertilisers in soil: solubility, diffusion and solid phase speciation. $19^{\text {th }}$ World Congress of Soil Science, Soil Solutions for a Changing World, Brisbane, Australia.

Møberg JP, Petersen L \& Borggaarg OK. 1994. Pedologiske Analysemetoder. Jordbrugs-forlaget.

Nowack B \& Buchelli TD. 2007. Occurrence, behavior and effects of NPs in the environment. Environ Pollut, 150: 5-22.

OECD (2004). Guideline for the testing of chemicals No. 222. Earthworm reproduction test

(Eisenia fetida/Eisenia andrei). Paris: Organization for Economic Cooperation and Development. 
Park S, Lee YK, Jung M, Kim KH, Chung N, Ahn E, Lim Y, Lee K. 2007. Cellular toxicity of various inhalable metal NPs on human alveolar epithelial cells. Inhal Toxicol, 19, 1: 59-65.

Paquin PR, Gorsuch JW, Apte S, Batley GE, Bowles KC, Campbell PGC, Delos CG, Di Toro DM, Dwyer RL, Galvez F, Gensemer RW, Goss GG, Hogstrand C, Janssen CR, McGeer JC, Naddy RB, Playle RC, Santore RC, Schneider U, Stubblefield WA, Wood CM, Wu KB. 2002. The biotic ligand model: a historical overview. Comp Biochem Phys C, 133, 1-2: 3-35.

Puzyn T, Rasulev B, Gajewicz A, Hu XK, Dasari TP, Michalkova A, Hwang HM, Toropov A, Leszczynska D, Leszczynski J. 2011. Using nano-QSAR to predict the cytotoxicity of metal oxide NPs. Nat Nanotechnol , 6: 175-178.

PROSPECT, (2009): Toxicological review of Nano Zinc Oxide. Available online at: www.nanotechiaprospect.org in publications menu.

PROSPECT, (2010). Protocol for NP Dispersion. Available online at: www.nanotechia-prospect.org.

R-project (2011). R version 2.13.1 Available online at: www.r-project.org.

Rothamsted Research (2011). Soil dry matter content and water holding capacity. Available online at: www.rothamsted.ac.uk/aen/smbweb1/methods.php

Santore RC, Matthew R., Paquin PR, DiToro D. 2002. Application of the biotic ligand model to predicting zinc toxicity to rainbow trout, fathead minnow, and Daphnia magna. Comp Biochem Phys C, $133,1-2: 271-285$, 
Shaw DJ.( 1970). Introduction to colloidal and surface chemistry. Butterworth-Heinemann Publications.

Smit CE \& Van Gestel CAM. 1998. Effects of soil type, prepercolation, and ageing on bioaccumulation and toxicity of zinc for the springtail Folsomia candida. Environ Toxicol Chem, 17: 1132-1141.

Spurgeon D J, Svendsen C, Rimmer VR, Hopkins SP, Weeks JM. 2000. Relative sensitivity of life-cycle and biomarker responses in four earthworm species exposed to zinc. Environ Toxicol Chem, 19: $1800-1808$.

Spurgeon D J, Hopkins SP, Jones DT. 1994. Effects of cadmium, copper, lead and zinc on growth, reproduction and survival of the earthworm Eisenia fetida (savigny): Assessing the environmental impact of point-source metal contamination in terrestrial ecosystems. Environ Pollut, 84: 123-130.

Spurgeon DJ \& Hopkins SP. 1996a. Effects of metal-contaminated soils on the growth, sexual development and early cocoon production of the earthworm Eisenia fetida, with particular reference to zinc. Ecotoxicol Environ Saf, 35: 86-95.

Spurgeon DJ \& Hopkin S P 1996b. Risk assessment of the threat of secondary poisoning by metals of predators of earthworms in the vicinity of a primary smelting works. Sci. Total Environ, 187: 167-183.

Suthar S \& Singh S. (2009). Bioconcentrations of metals ( $\mathrm{Fe}, \mathrm{Cu}, \mathrm{Zn}, \mathrm{Pb}$ ) in earthworms (Eisenia fetida), inoculated in municipal sewage sludge: Do earthworms pose a possible risk of terrestrial food chain contamination? Wiley InterScience. 
Tipping E, Rieuwerts J, Pan G, Ashmorec MR, Lofts S, Hill MTR, Farago ME, Thornton I. 2003. The solid-solution partitioning of heavy metals $(\mathrm{Cu}, \mathrm{Zn}, \mathrm{Cd}, \mathrm{Pb})$ in upland soils of England and Wales. Environ Pollut, 125: 213-225.

Unrine J, Hunyadi SE, Tsyusko O, Rao W, Shoults-Wilson WA, Bertsch PM. 2010a. Evidence for bioavailability of Au NPs from soil and biodistribution within earthworms (Eisenia fetida). Environ Sci Technol, 44, 21: 8308-8313.

Unrine J, Tsyosko OV, Hunyadi SE, Judy JD, Bertsch PM. 2010b. Effects of particle size on chemical speciation and bioavailability of copper to earthworms (Eisenia fetida) exposed to copper NPs. J Environ Qual, 39, 6: 1942-1953.

Van Breemen N, Mulder J, Driscoll CT. 1983. Acidification and alkalinization of soils. Plant Soil 75, 283-308.

van der Ploeg MJC, Baveco JM, van der Hout A, Bakker R, Rietjens IMCM \& van den Brink NW. 2011. Effects of $\mathrm{C}_{60} \mathrm{NP}$ exposure on earthworms (Lumbricus rubellus) and implications for population dynamics. Environ Pollut, 159, 1: 198-203.

van Gestel CAM, Dirven-Van Breemen EM, Baerselman R. 1993. Accumulation and elimination of cadmium, chromium and zinc and effects on growth and reproduction in Eisenia andrei (Oligochaeta, Annelida). Sci Tot Environ, Supplement Part 1: 585-597.

van Gestel CAM, Kool PL, Diez Ortiz M. 2010. Metal-based nanoparticles in soil: New research themes should not ignore old rules and theories. Comments on the paper by Hu et al. (2010) 
'Toxicological effects of $\mathrm{TiO}(2)$ and $\mathrm{ZnO}$ nanoparticles in soil on earthworm Eisenia fetida.' Soil Biol Biochem, 42: 586-591.

van Gestel CAM, van Dis WA, van Breemen EM, Sparenburg PM. 1989. Development of a standardized reproduction toxicity test with the earthworm species Eisenia andrei using copper, pentachlorophenol and 2,4- dichloroaniline. Ecotox. Environ. Saf., 18: 305-312.

Vijver MG, Vink JPM, Miermans CJH \& van Gestel CAM. 2003. Oral sealing using glue: a new method to distinguish between intestinal and dermal uptake of metals in earthworms. Soil Biol Biochem, 35, 1: $125-132$.

Waalewijn-Kool PL, Diez-Ortiz M, van Gestel CAM, 2012. Effect of different spiking procedures on the distribution and toxicity of ZnO nanoparticles in soil. Ecotoxicology, 21, 7, 1797-1804.

Waalewijn-Kool PL, Diez Ortiz M, Lofts S, van Gestel CAM 2013. The effect of pH on the toxicity of ZnO nanoparticles to Folsomia candida in amended field soil. Environ Toxicol Chem (submitted).

Yamabi S \& Imai H. 2002. Growth conditions for wurtzite zinc oxide films in aqueous solutions. J Mater Chem, 12: 3773-3778. 


\section{Tables}

Table 1. Characterization data for the dosing soil suspensions. The $\mathrm{pHss}$ refers to the $\mathrm{pH}$ measured in the soil suspension before and after spiking with 30nM ZnONPs. The size measurement is the zaverage $(n m) \pm S E(n=3)$ of hydrodynamic size of particles present in the media and $\zeta$ - potential is the average $(m V) \pm S E(n=3)$ zeta potential of the NPs.

Table 2. Pore water characterization data from the dynamic light scattering analysis. At the start of exposure, pore water samples were extracted from: unspiked control soils, soils spiked with low (235 mg Zn/kg), and high concentration ( $2500 \mathrm{mg} \mathrm{Zn/kg)} \mathrm{concentrations} \mathrm{of} 30 \mathrm{nmZnONPs}$. The $\mathrm{pH}_{\mathrm{pw}}$ refers to $\mathrm{pH}$ measured in the pore water extract. The size measurement is the z-average of hydrodynamic size $(n m) \pm S E(n=3)$ of particles present in the media and $\zeta$ - potential $(m V) \pm S E(n=3)$ is the zeta potential of these particles.

Table 3. LC50 values (+/- SE) for the effect of $\mathrm{ZnCl}_{2}, \mathrm{ZnO}$ NPs and non-nano $\mathrm{ZnO}$ on the survival of the earthworm Eisenia fetida after 28 days exposure in a natural sandy soils at a low, medium and high $\mathrm{pH}$. The (-) indicates that data did not allow calculating standard error.

Table 4. EC50 values (+/- SE) for the effects of $\mathrm{ZnCl}_{2}, \mathrm{ZnO} \mathrm{NPs}$, and non-nano scale $\mathrm{ZnO}$ on the cocoon production of the earthworm Eisenia fetida after 28 days exposure in a natural sandy soils at a low, medium and high $\mathrm{pH}$.

Table 5. Calculated bioaccumulation factors (BAF) +/- SD calculated as earthworm tissue $\mathrm{Zn}$ concentrations / total soil $\mathrm{Zn}$ concentration and bioconcentration factors (BCF) +/- SD calculated as earthworm tissue $\mathrm{Zn}$ concentrations / soil pore water $\mathrm{Zn}$ concentration. Values are based on BAFs and BCFs derived for all treatment resulting in effects below EC50 for reproduction with control 
1

2

3

4

5

6

7

8

9

10

11

12

13

14

15

16

17

18

19

20

21

22

23

24

25

26

27

28

29

30

31

32

33

34

35

36

37

38

39

40

41

42

43

44

45

46

47

48

49

50

51

52

53

54

55

56

57

58

59

60 treatments excluded as difference in speciation can be expected in these unspiked soils compared to the spiked treatment. 


\section{Figures}

Figure 1. The measured total zinc concentrations in a single sample of soil pore water collected for each concentrations of A) $\mathrm{ZnCl}_{2}$, B) $\mathrm{ZnO} \mathrm{NPs}$ and C) non-nano scale $\mathrm{ZnO}$ for thelow pH soil $(\diamond)$, medium pH soil( $\square)$, and high $\mathrm{pH}$ soil $(\triangle)$, including separate analysis for samples at the beginning of the toxicity test ( $t=0$, solid line) and at experiment completion ( $t=56$, dashed line).

Figure 2. The cocoon production rate of Eisenia fetida in low pH soil $(\diamond)$, medium pH soil $(\square)$, and high $\mathrm{pH}$ soil $(\triangle)$ after 28 days exposure to $\left.\mathrm{A}-\mathrm{B}) \mathrm{ZnCl}_{2}, \mathrm{C}-\mathrm{D}\right) \mathrm{ZnO} \mathrm{NPs}$ and $\mathrm{E}-\mathrm{F}$ ) non-nano scale $\mathrm{ZnO}$. The left hand colum of graphs (A, C, E) plots cocoon production rate in relation to total nominal zinc concentration in the soil, and the right hand column of graphs (graphs B, D, F) plots rate as a function of pore water zinc concentration. Solid, dashed and punctured lines show fit obtained with a logistic model for the low, medium and high $\mathrm{pH}$ soils, respectively.

Figure 3. Internal Zn concentration ( $\mu \mathrm{g} \mathrm{Zn} / \mathrm{g}$ d.w.) in the earthworm Eisenia fetida exposed in low pH $(\diamond)$, medium $\mathrm{pH}(\square)$, and high $\mathrm{pH}(\triangle)$ soil to $\mathrm{ZnCl}_{2}(\mathrm{~A}), \mathrm{ZnO}$ nanoparticles $(\mathrm{B})$ and non-nano $\mathrm{ZnO}(\mathrm{C})$ after 28 days of exposure. Bars represented standard errors. Letters indicate significant difference from the respective control soil (Tukey, $\mathrm{p}<0.05$ ) for (a) low, (b) medium and (c) high pH soil. Note variation for $y$-axis scale. 


\section{Supplementary Material}

Table S1. Summary of the soil properties of the unchanged Dorset soil used for all toxicity tests prior to $\mathrm{pH}$ amendment. Dorset soil texture, $\mathrm{pH}$ (in water and $0.01 \mathrm{M} \mathrm{CaCl}_{2}$ ), conductivity, total carbon (\% Total C) and nitrogen (\% Total $\mathrm{N})$, cation exchange capacity (CEC), percent base saturation (\% BS), major cations concentrations $\left(\mathrm{Ca}^{2+}, \mathrm{Mg}^{2+}, \mathrm{K}^{+}\right.$and $\left.\mathrm{Na}^{+}\right)$along with oxalate $\left(\% \mathrm{Fe}_{\mathrm{ox}}, \% \mathrm{Al}_{\mathrm{ox}}\right)$ and citratebicarbonate-dithionite (\% $\mathrm{Fe}_{\mathrm{CBD}}$ and $\% \mathrm{Al}_{\mathrm{CBD}}$ ) extractable iron and aluminium are shown.

Table S2. Levels of calcium carbonate addition and final $\mathrm{pH}$ in Dorset sandy soil with original properties shown in Table S1 as used for the low, medium and high pH soils.

Table S3. Characterisation results for Nanosun P99/30 and non nano scale ZnO P99/200 with XRD, BET and density measurements

Figure S1. NanoSun P99/30 ZnO (A) and non nano scale ZnO (B) observed in a transmission electron microscope.

Figure S2. TEM images of the three $\mathrm{ZnO}$ nanoparticle stock soil suspensions. A) low pH, B) medium $\mathrm{pH}, \mathrm{C})$ high $\mathrm{pH}$.

Figure S3. The measured total organic carbon concentration in the soil pore water of the low pH soil $(\diamond)$, medium pH soil $(\square)$, and high pH soil $(\Delta)$ spiked with $\mathrm{ZnO}$ nanoparticles as a function of $\mathrm{Zn}$ pore water concentration (mg $\mathrm{Zn} / \mathrm{L}$ ). The solid lines reflect time zero and punctured lines reflect time 56 days.

Figure S4. The survival of Eisenia fetida in low pH soil $(\bullet)$, medium pH soil $(\square)$, and high pH soil $(\triangle)$ after four weeks exposure to $\mathrm{A}-\mathrm{B}) \mathrm{ZnCl}_{2}, \mathrm{C}-\mathrm{D}$ ) $\mathrm{ZnO}$ nanoparticles and $\mathrm{E}-\mathrm{F}$ ) $\mathrm{ZnO}$. The left hand column 
(graphs A, C, E) express the survival as a function total nominal zinc concentration in the soil, and the right hand column survival (graphs B, D, F) as a function of zinc concentration in the pore water. Small letters (a) indicate significant difference between control and treatments (Tukey, $p<0.05$ ). Solid, dashed and punctured lines show fit obtained with a logistic model for the low, medium and high pH soils, respectively. 
Figure 1.

A)

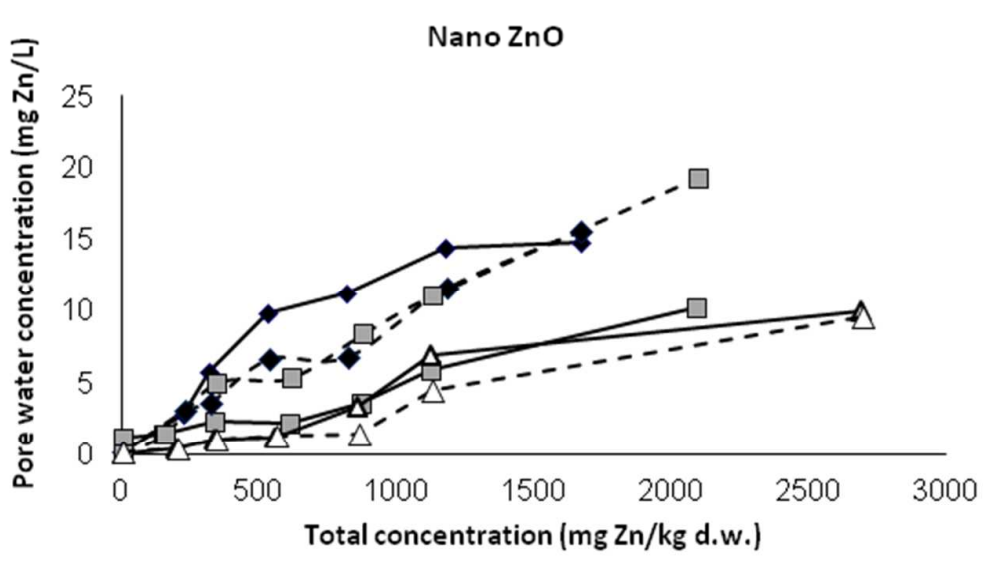

B)

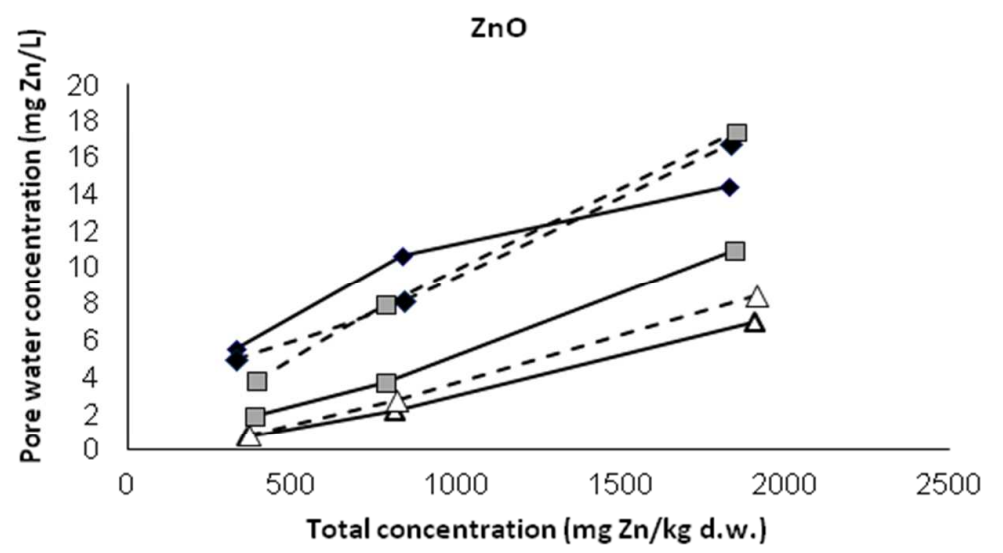

C)

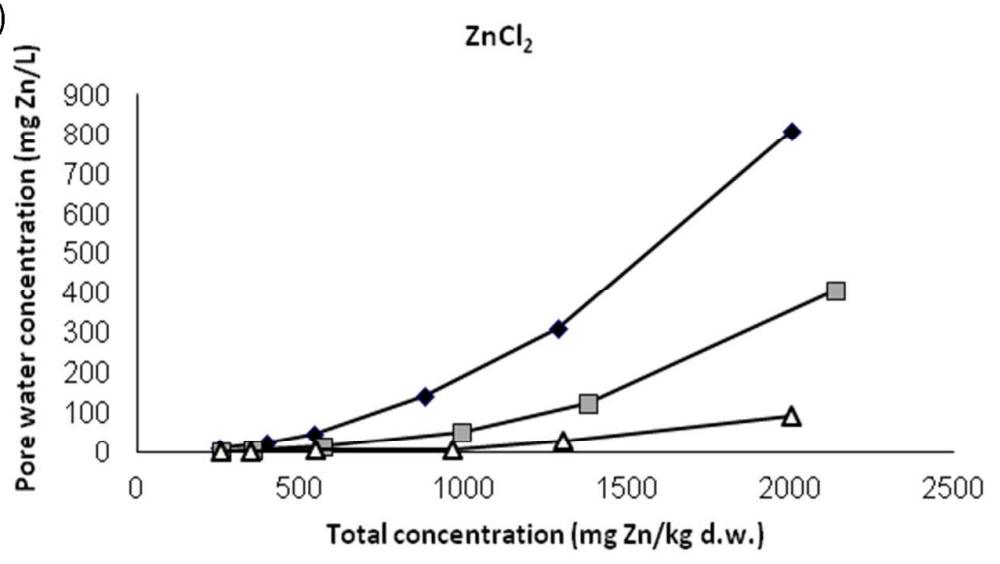

URL: http://mc.manuscriptcentral.com/tnan 
Figure 2.

A)

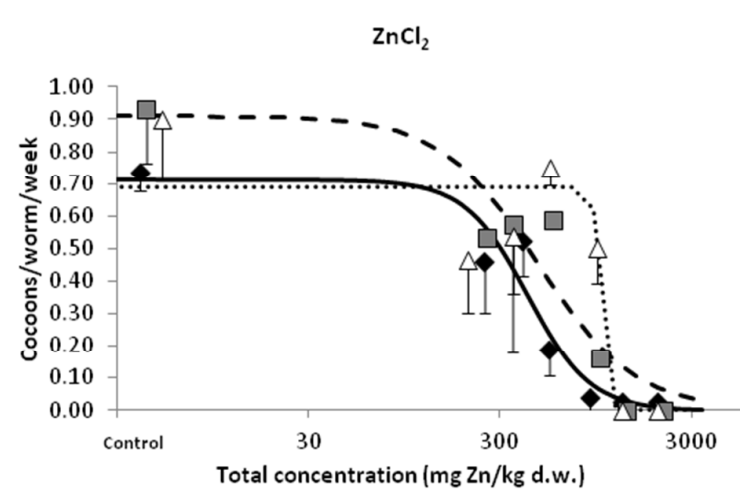

C)

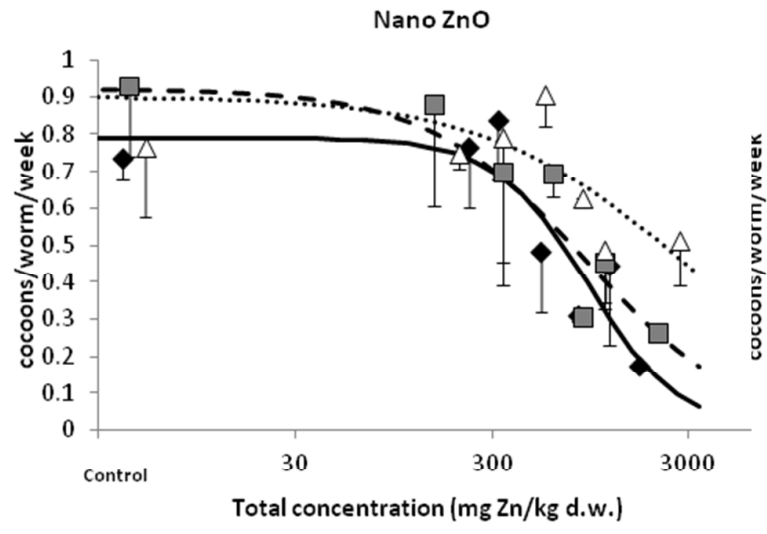

E)

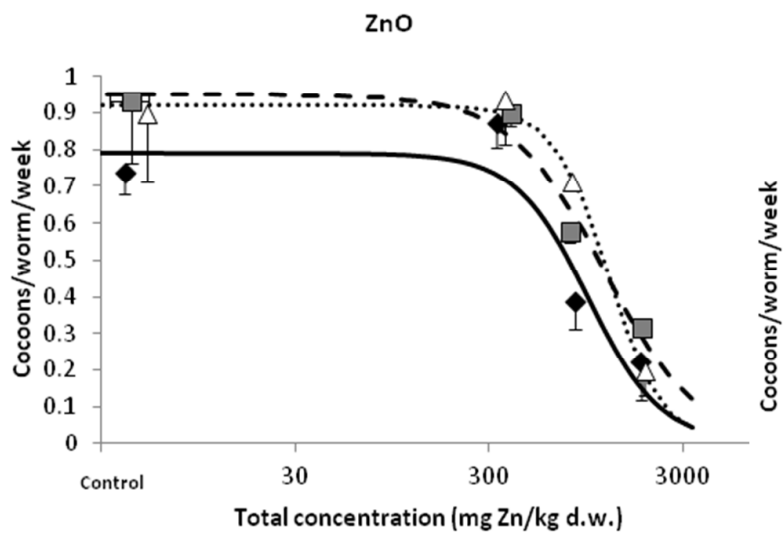

B)

D)

F)
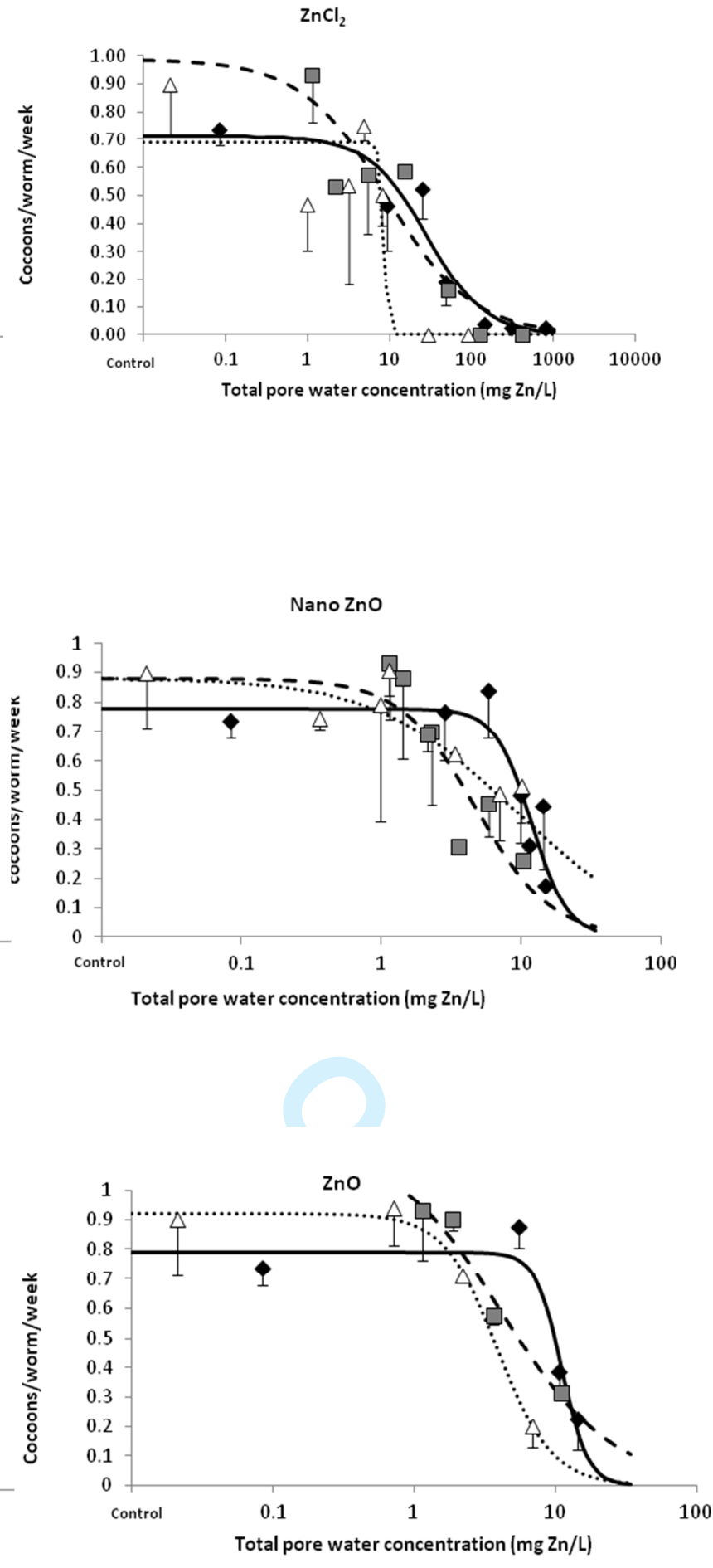
Figure 3.

A. $\mathrm{ZnCl}_{2}$

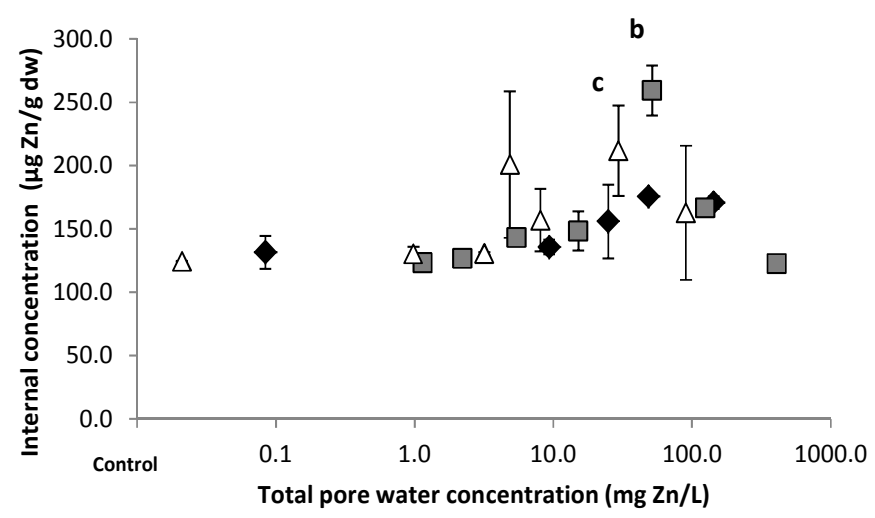

B. Nano ZnO

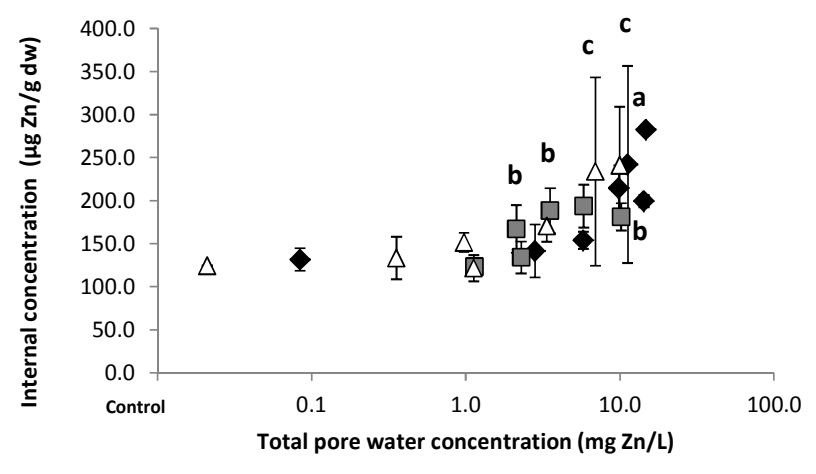

C. ZnO

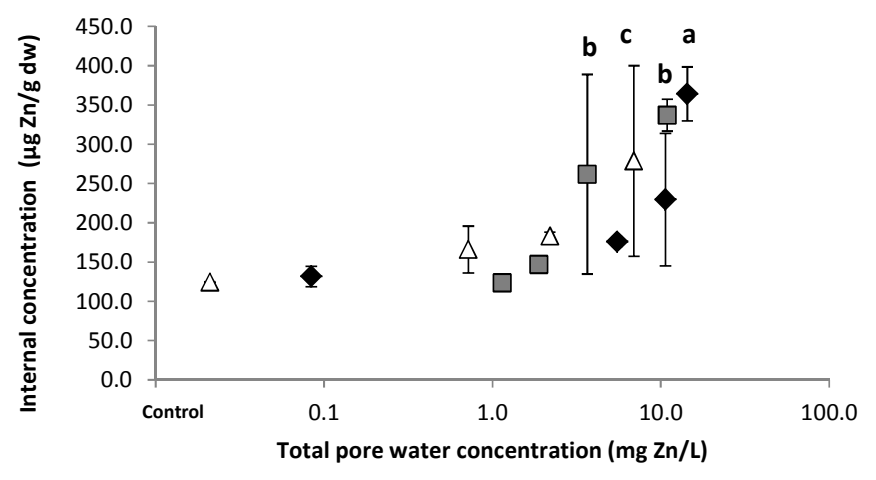

URL: http://mc.manuscriptcentral.com/tnan 
Table 1. Characterization data for the dosing soil suspensions. The $\mathrm{pH}_{\mathrm{ss}}$ refers to the $\mathrm{pH}$ measured in the soil suspension before and after spiking with $30 \mathrm{nM}$ ZnONPs. The size measurement is the z-average $(n m) \pm S E(n=3)$ of hydrodynamic size of particles present in the media and $\zeta$ - potential is the average $(m V) \pm S E(n=3)$ zeta potential of the NPs.

\begin{tabular}{lcccccc}
\hline \multicolumn{3}{c}{ Unspiked soil suspensions } & \multicolumn{5}{c}{ Spiked soil suspensions } \\
\hline Soil & $\mathrm{pH}_{\mathrm{ss}}$ & Size & $\zeta$ - potential & $\mathrm{pH}_{\mathrm{ss}}$ & Size & $\zeta$ - potential \\
Low pH & 5.1 & $2228 \pm 172$ & $-16.3 \pm 0.5$ & 6.2 & $720 \pm 1036$ & $0.7 \pm 0.05$ \\
Medium pH & 6.4 & $1107 \pm 90$ & $-16 \pm 0.9$ & 7.5 & $614 \pm 192$ & $0.8 \pm 0.5$ \\
High pH & 7 & $1476 \pm 133$ & $-12.4 \pm 0.6$ & 8 & $653 \pm 142$ & $1.3 \pm 0.2$ \\
\hline
\end{tabular}


Table 2. Pore water characterization data from the dynamic light scattering analysis. At the start of exposure, pore water samples were extracted

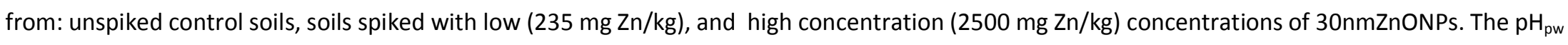
refers to $\mathrm{pH}$ measured in the pore water extract. The size measurement is the $z$-average of hydrodynamic size $(n m) \pm S E(n=3)$ of particles present in the media and $\zeta$ - potential $(\mathrm{mV}) \pm S E(n=3)$ is the zeta potential of these particles.

\begin{tabular}{lccccccccc}
\hline & \multicolumn{3}{c}{ Pore water (control soils) } & \multicolumn{3}{c}{ Pore water - low Zn concentration } & \multicolumn{2}{l}{ Pore water - high Zn concentration } \\
\hline Soil & $\mathrm{pH}_{\mathrm{pw}}$ & Size & $\zeta$ - potential & $\mathrm{pH}_{\mathrm{pw}}$ & Size & $\zeta$ - potential & $\mathrm{pH}_{\mathrm{pw}}$ & Size & $\zeta$ - potential \\
Low pH & 5.2 & $199 \pm 3$ & $-20.3 \pm 0.5$ & 5.3 & $237 \pm 4$ & $-17.6 \pm 1.2$ & 6.3 & $202 \pm 4$ & $-9.9 \pm 1.7$ \\
Medium pH & $6.4^{*}$ & $402 \pm 5$ & $-17.2 \pm 1.7$ & 7.2 & $285 \pm 49$ & $-14 \pm 0.7$ & 7.5 & $119 \pm 6$ & $-14.1 \pm 2.4$ \\
High pH & 8.2 & $604 \pm 67$ & $-11.4 \pm 0.7$ & 8.1 & $429 \pm 15$ & $-14.2 \pm 1.8$ & 7.7 & $247 \pm 28$ & $-12.1 \pm 0.7$ \\
\hline
\end{tabular}

*Due to a very small volume of available sample a pH measurement could not be obtained. This value refers to the $\mathrm{pH}$ in the unspiked soil suspension made from the same soil which is assumed to be similar. 
Table 3. $\mathrm{LC}_{50}$ values (+/- SE) for the effect of $\mathrm{ZnCl}_{2}, \mathrm{ZnO} \mathrm{NPs}$ and non-nano $\mathrm{ZnO}$ on the survival of the earthworm Eisenia fetida after 28 days exposure in a natural sandy soils at a low, medium and high $\mathrm{pH}$. The (-) indicates that data did not allow calculating standard error.

\begin{tabular}{|c|c|c|c|c|}
\hline & 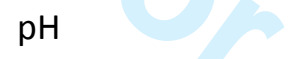 & $\mathrm{ZnCl}_{2}$ & Nano ZnO & $\mathrm{ZnO}$ \\
\hline \multicolumn{5}{|c|}{$\mathrm{LC}_{50}$ based on } \\
\hline Zn in soil & Low & $718 \pm 73.6$ & >> $1669(-)$ & >> $1832(-)$ \\
\hline \multirow[t]{2}{*}{ (mg Zn/kg) } & Medium & $589.5 \pm 72.7$ & >> $2094(-)$ & $4147 \pm 2751$ \\
\hline & High & $1983 \pm 285.8$ & $>2689(-)$ & >> $1908(-)$ \\
\hline \multicolumn{5}{|c|}{$\mathrm{LC}_{50}$ based on } \\
\hline \multicolumn{5}{|c|}{ Zn in pore } \\
\hline water & Low & $89.4 \pm 16.4$ & >> $14.8(-)$ & >> $14.38(-)$ \\
\hline \multirow[t]{2}{*}{ (mg Zn/L) } & Medium & $20.1 \pm 4.8$ & >> $10.2(-)$ & $13.8 \pm 5.5$ \\
\hline & High & $76.9 \pm 24.2$ & $>>9.98(-)$ & >> $6.93(-)$ \\
\hline
\end{tabular}


Table 4. $\mathrm{EC}_{50}$ values (+/- SE) for the effects of $\mathrm{ZnCl}_{2}, \mathrm{ZnO}$ NPs, and non-nano scale $\mathrm{ZnO}$ on the cocoon production of the earthworm Eisenia fetida after 28 days exposure in a natural sandy soils at a low, medium and high $\mathrm{pH}$.

\begin{tabular}{llccc}
\hline & $\mathrm{pH}$ & $\mathrm{ZnCl}_{2}$ & Nano ZnO & ZnO \\
\hline $\begin{array}{l}\mathrm{EC}_{50} \text { based on } \\
\text { Zn in soil }\end{array}$ & Low & & & \\
(mg Zn/kg) & Medium & $420.4 \pm 97$ & $918.6 \pm 222$ & $985.4 \pm 194.7$ \\
& High & $472.2 \pm 110$ & $901 \pm 243.2$ & $1171.5 \pm 225.3$ \\
EC 5 based on & & $1002 \pm 308$ & $2874 \pm 1799$ & $1241 \pm 188$ \\
Zn in pore & & & & \\
water & Low & & & $11.1 \pm 0.9$ \\
(mg Zn/L) & Medium & $28.5 \pm 14.6$ & $11.8 \pm 1.4$ & $4.2 \pm 2.8$ \\
& High & $9.3 \pm 16$ & $4.7 \pm 1$ & $3.9 \pm 0.7$ \\
\hline
\end{tabular}


Table 5. Calculated bioaccumulation factors (BAF) +/- SD calculated as earthworm tissue Zn concentrations / total soil Zn concentration and bioconcentration factors (BCF) +/- SD calculated as earthworm tissue $\mathrm{Zn}$ concentrations / soil pore water Zn concentration. Values are based on BAFs and $\mathrm{BCFs}$ derived for all treatment resulting in effects below $\mathrm{EC}_{50}$ for reproduction with control treatments excluded as difference in speciation can be expected in these unspiked soils compared to the spiked treatment.

\begin{tabular}{|c|c|c|c|c|c|c|}
\hline & & BAF & & & $\mathrm{BCF}$ & \\
\hline Soil & $\mathrm{ZnCl}_{2}$ & Nano ZnO & $\mathrm{ZnO}$ & $\mathrm{ZnCl}_{2}$ & Nano ZnO & $\mathrm{ZnO}$ \\
\hline Low $\mathrm{pH}$ & $0.47 \pm 0.12$ & $0.46 \pm 0.16$ & $0.41 \pm 0.19$ & $10.4 \pm 5$ & $29.9 \pm 14$ & $26.7 \pm 11$ \\
\hline Medium pH & $0.39 \pm 0.11$ & $0.48 \pm 0.27$ & $0.36 \pm 0.13$ & $31.2 \pm 21$ & $77.7 \pm 22$ & $74.7 \pm 27$ \\
\hline High pH & $0.34 \pm 0.14$ & $0.33 \pm 0.2$ & $0.3 \pm 0.16$ & $56.8 \pm 49$ & $134.4 \pm 127$ & $139.9 \pm 90$ \\
\hline
\end{tabular}




\section{Page 51 of 58}

Nanotoxicology

Supplementary Material

URL: http://mc.manuscriptcentral.com/tnan 
Table S1. Summary of the soil properties of the unchanged Dorset soil used for all toxicity tests prior to $\mathrm{pH}$ amendment. Dorset soil texture, $\mathrm{pH}$ (in water and $0.01 \mathrm{M} \mathrm{CaCl}_{2}$ ), conductivity, total carbon (\% Total C) and nitrogen (\% Total $\mathrm{N}$ ), cation exchange capacity (CEC), percent base saturation (\% $\mathrm{BS})$, major cations concentrations $\left(\mathrm{Ca}^{2+}, \mathrm{Mg}^{2+}, \mathrm{K}^{+}\right.$and $\left.\mathrm{Na}^{+}\right)$along with oxalate $\left(\% \mathrm{Fe}_{\mathrm{ox}}, \% \mathrm{Al}_{\mathrm{Ox}}\right)$ and citrate-bicarbonate-dithionite $\left(\% \mathrm{Fe}_{\mathrm{CBD}}\right.$ and \% $\left.\mathrm{Al}_{\mathrm{CBD}}\right)$ extractable iron and aluminium are shown.

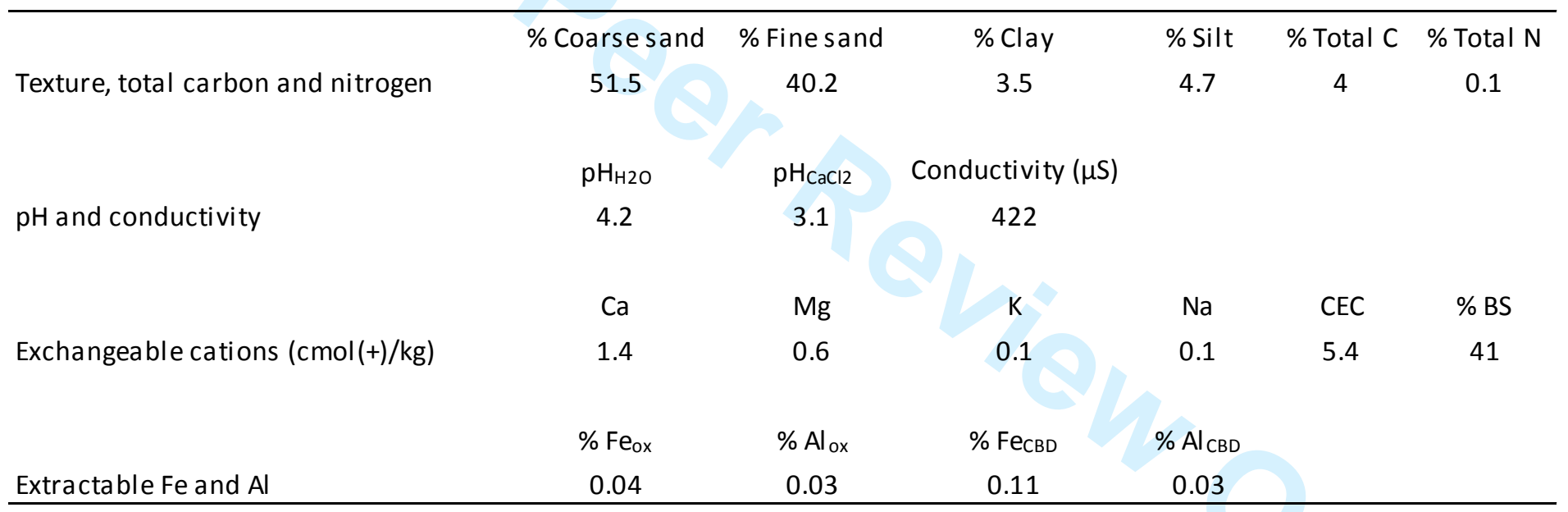



and high pH soils.

\begin{tabular}{lcc}
\hline Soil & $\mathrm{CaCO}_{3}(\mathrm{w} / \mathrm{w} \%)$ & $\mathrm{pH}^{\mathrm{a}}$ \\
Low pH & 0.2 & 4.5 \\
Medium pH & 0.45 & 5.9 \\
High pH & 1 & 7.2 \\
\hline
\end{tabular}

${ }^{a} \mathrm{pH}$ measured in $0.01 \mathrm{M} \mathrm{CaCl}_{2}, \mathrm{n}=4$ 
Table S3. Characterisation results for Nanosun P99/30 and non nano scale ZnO P99/200 with XRD, BET and density measurements

\begin{tabular}{||c|c|c||}
\hline Manufacturer name & NanoSun P99/30 ZnO & Non nano scale ZnO \\
\hline \hline XRD & No alienphases & No alien phases \\
\hline $\begin{array}{c}\text { Average crystallite size } \\
\text { from Scherrer's formula } \\
\text { (XRD): }\end{array}$ & $\mathrm{a}=25 \mathrm{~nm}$ & $\mathrm{a}=72 \mathrm{~nm}$ \\
& $\mathrm{c}=27 \mathrm{~nm}$ & $77 \mathrm{~nm}$ \\
\hline $\begin{array}{c}\text { Grain size from SSA BET: } \\
\text { Specific Surface Area (BET): }\end{array}$ & $29 \mathrm{~nm}$ & $296 \mathrm{~nm}$ \\
\hline Density: & $38 \mathrm{~m}^{2} / \mathrm{g}$ & $3,59 \mathrm{~m}^{2} / \mathrm{g}$ \\
\hline Zeta potential in DI water & $5,52 \mathrm{~g} / \mathrm{cm}^{3}$ & $5,67 \mathrm{~g} / \mathrm{cm}^{3}$ \\
\hline
\end{tabular}




\section{Page 55 of 58}

Nanotoxicology

Figure S1.

A)
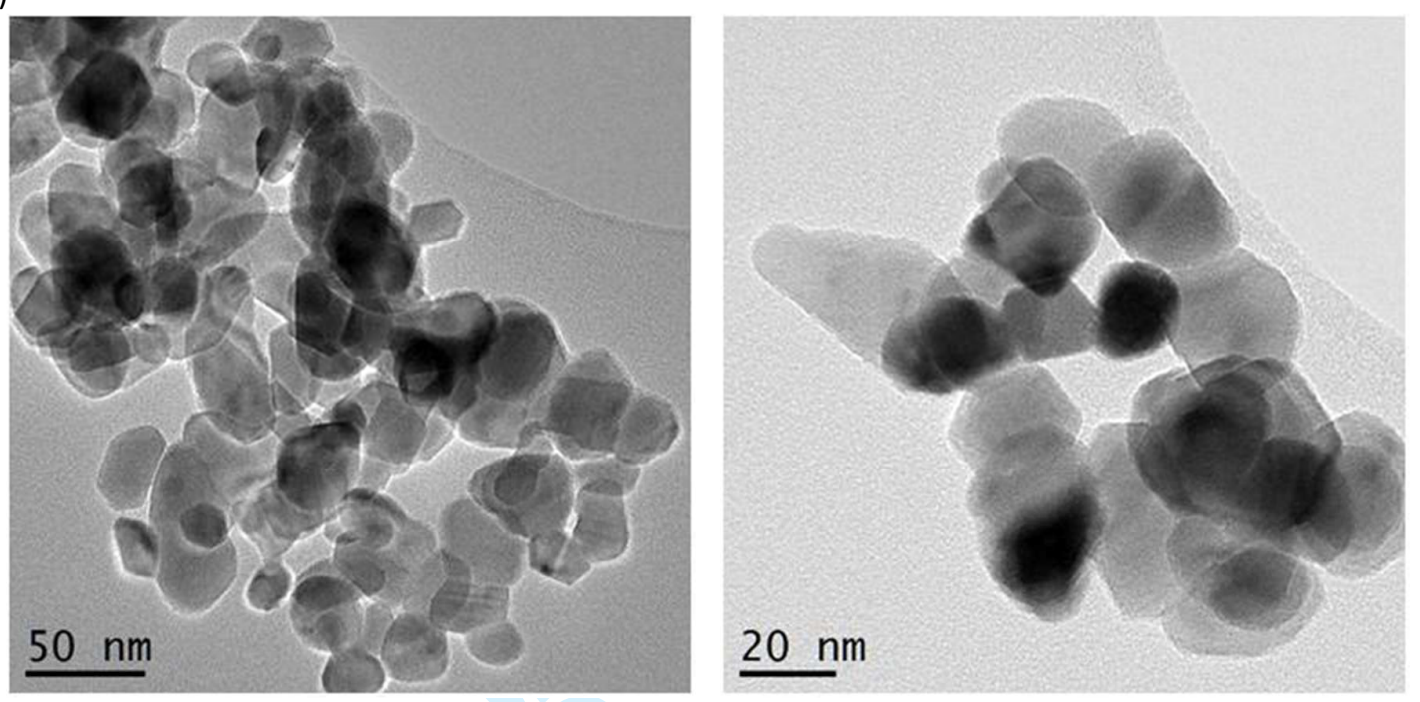

B)
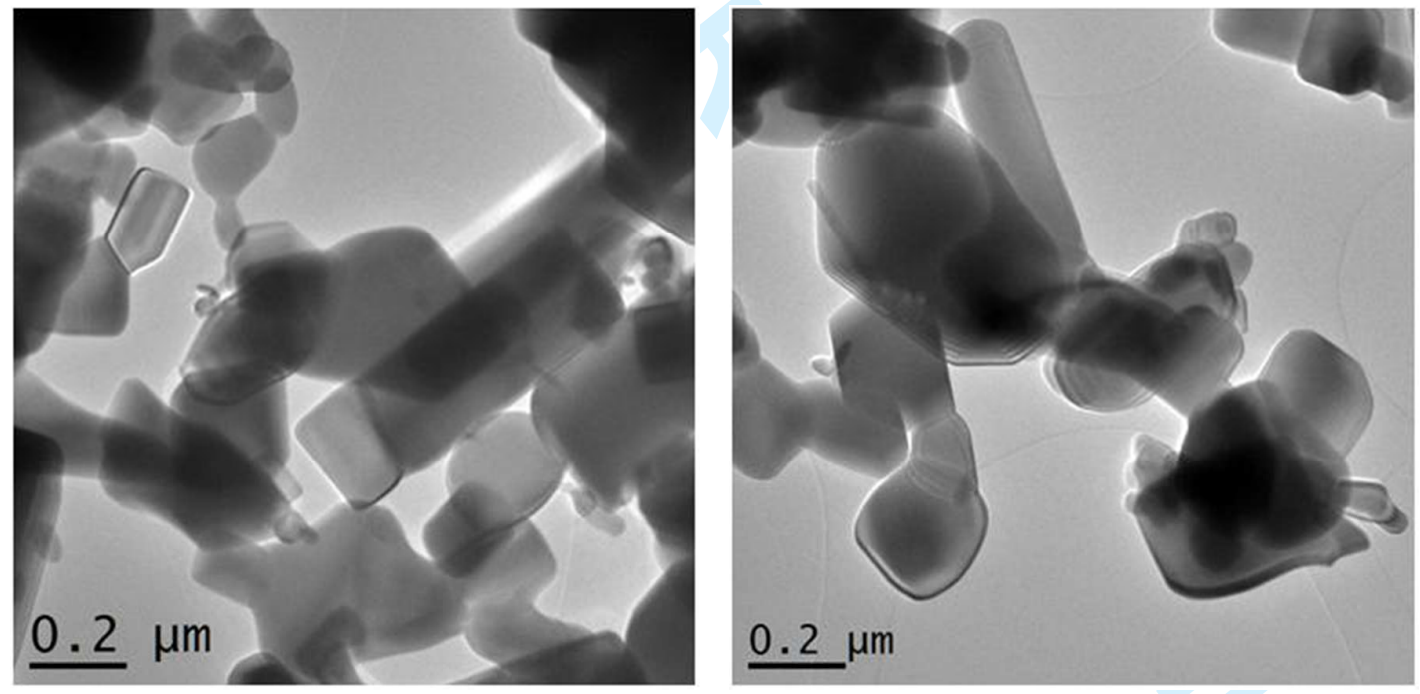
Figure S2.

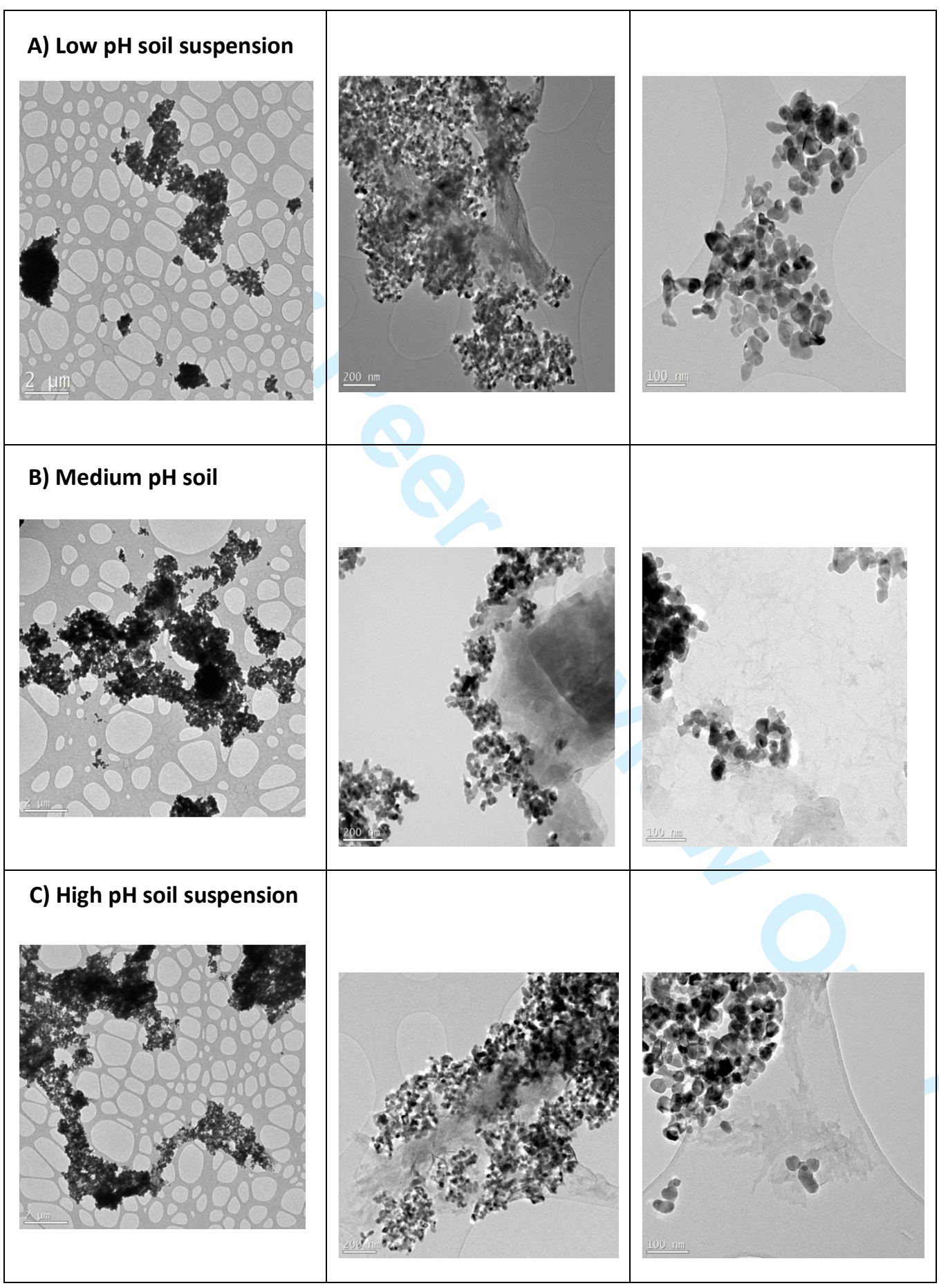

URL: http://mc.manuscriptcentral.com/tnan 
Figure S3.

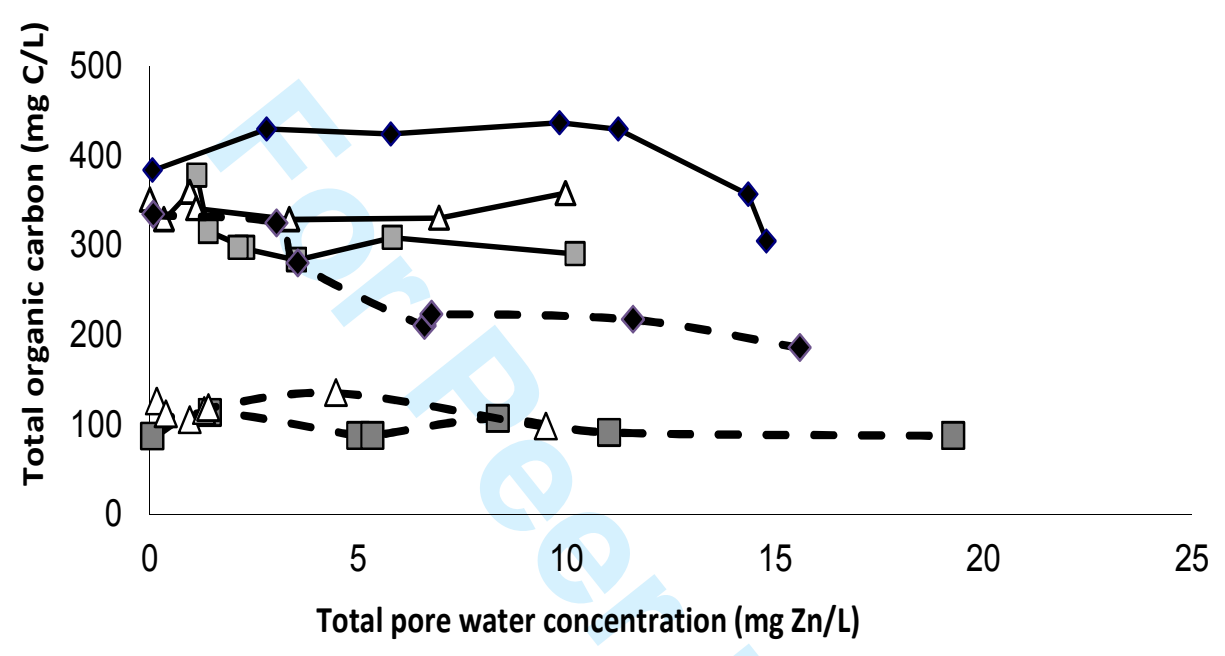

URL: http://mc.manuscriptcentral.com/tnan 
Figure S4.

B
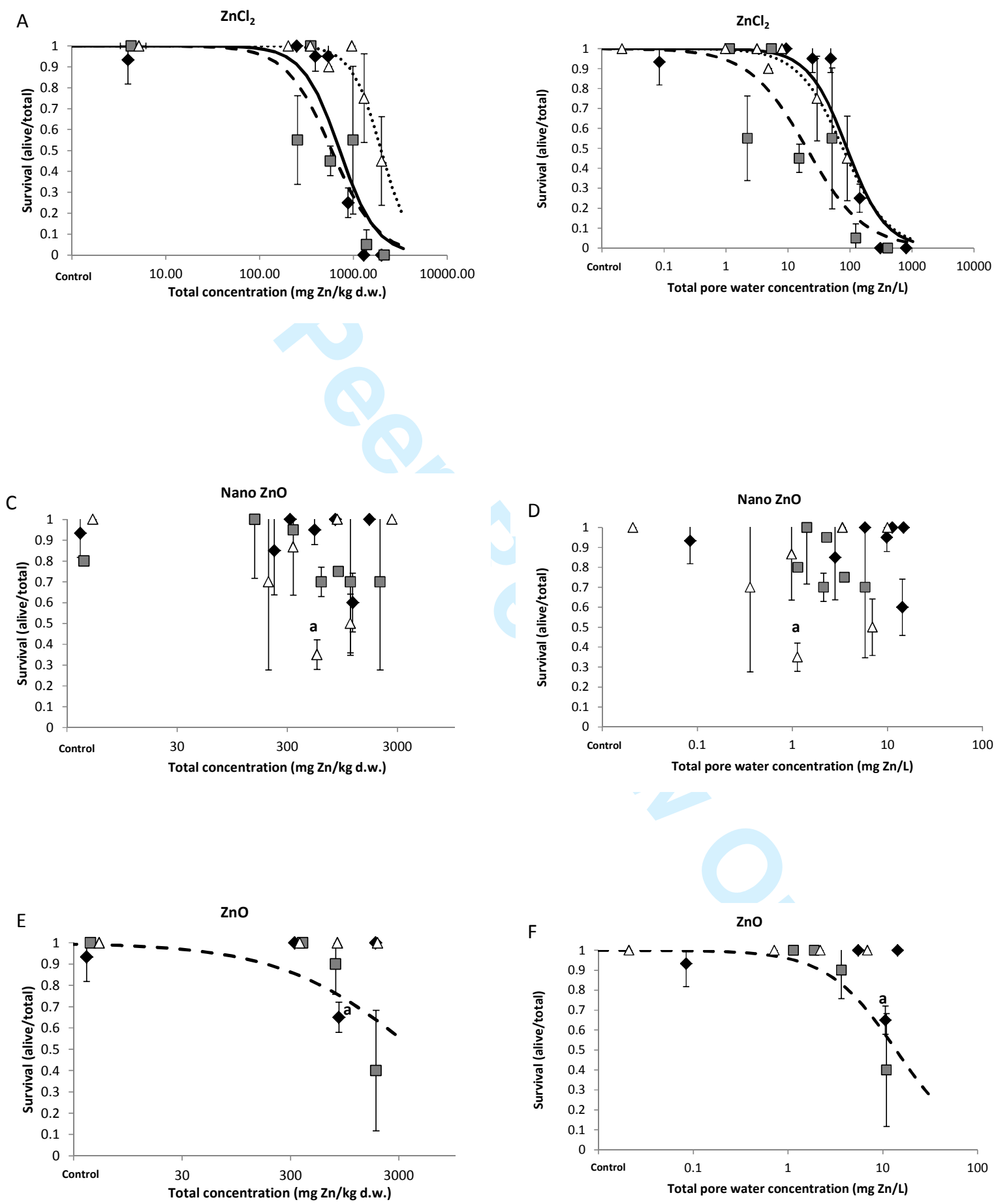

URL: http://mc.manuscriptcentral.com/tnan 